\title{
HYBRID PHOTOVOLTAIC/THERMAL SOLAR ENERGY SYSTEMS
}

\author{
Edward C. Kern, Jr. \\ Miles C. Russell
}

This report was prepared as an accoutit of work

ponsored by the United States Govemment. Neither the

United States nor the United States Department of

Energy, nor sny of their employees, nor any of their

contractors, subcontractors, or their employees, makes

any warranty, express or implied, or assumes any legal

liability or responsibility for the accuracy, comple teness

or usefulness of any information, apparatus, product or

process disclosed, or represents that its use would not

infringe privately owned rights.

COO-4577-1

27 March 1978

\section{Massachusetts Institute of Technology \\ Lincoln Laboratory \\ Lexington, Massachusetts 02173}




\section{DISCLAIMER}

This report was prepared as an account of work sponsored by an agency of the United States Government. Neither the United States Government nor any agency Thereof, nor any of their employees, makes any warranty, express or implied, or assumes any legal liability or responsibility for the accuracy, completeness, or usefulness of any information, apparatus, product, or process disclosed, or represents that its use would not infringe privately owned rights. Reference herein to any specific commercial product, process, or service by trade name, trademark, manufacturer, or otherwise does not necessarily constitute or imply its endorsement, recommendation, or favoring by the United States Government or any agency thereof. The views and opinions of authors expressed herein do not necessarily state or reflect those of the United States Government or any agency thereof. 


\section{DISCLAIMER}

Portions of this document may be illegible in electronic image products. Images are produced from the best available original document. 


\begin{abstract}
Heating and cooling systems that use hybrid solar energy collectors (combination photovoltaic-thermal) have the potential for considerable energy savings, particularly when the system includes a heat pump. Economic evaluations show that photovoltaic systems are potentially most economical, but results depend critically on future collector costs as well as energy prices. Results are based on a specially developed computer program that predicted the total auxiliary energy required for five different solar heating/cooling systems. Performance calculations for a modeled residence and small office building were made using meteorological data from four geographic locations. Annual system costs were also calculated.
\end{abstract}




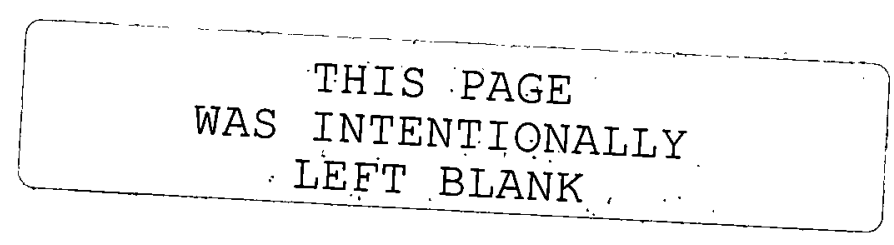




\section{CONTENTS}

Abstract

iii

INTRODUCTION

SYSTEM CONFIGURATIONS 1

1. Direct Solar Heating and Vapor-Compression 1 Air Conditioning

2. Parallel Heat Pump . . 3

3. Series Heat Pump 4

4. Absorption Air Chiller ‥ 5

5. Series Advanced Heat Pump 6

6. Conventional System 7

Climatic Regions 7 .

ANALYTIC APPROACHES $\quad \cdot \quad 8$

Average Performance Model (APM) 8

Components 12

1. Collectors 12

2. Standard Heat Pump 13

3. Vapor-Compression Air Conditioner 13

4. Advanced Heat Pump 13

5. Absorption Chiller 14

Detailed Simulation $\quad 14$

Solar-Thermal Subsystem 15

Solar-Photovoltaic Subsystem 16

Methods Comparison $\quad 17$

$\begin{array}{ll}\text { ECONOMIC ANALYSES } & 18\end{array}$

$\begin{array}{ll}\text { CONCLUSIONS } & 19\end{array}$

Technical Performance Results $\quad 19$

Economic Evaluation Results 26 
INTRODUCTION

A hybrid solar energy collector combines a photovoltaic module and a solar thermal collector in a single unit. This is accomplished most simply by affixing photovoltaic cells on the absorber surface of a flat-plate thermal collector. This "hybrid" collector provides (a) thermal energy by active cooling of the photovoltaic cells, and (b) electrical energy that is generated by the cells. Systems that use hybrid collector power to meet a particular demand, such as the heating/air conditioning load in a residence, are called hybrid energy systems.

Massachusetts Institute of Technology/Lincoln Laboratory is under contract to the United States Department of Energy (DOE) to (a) consider hybrid solar applications of different types, (b) appraise the performance of several system configurations, (c) assess the merit of these systems in a range of climate zones, and (d) develop and field-test hybrid energy systems:

In this study, hybrid systems are compared with solar thermal and photovoltaic systems, and evaluated from energy-savings and system-cost standpoints. The performance of these systems was calculated for both office building and residential applications in four geographic locations. This paper presents the results of the study.

SYSTEM CONFIGURATIONS

Five different heating and cooling systems for a small (10,000-sq $\mathrm{ft}$ ) office building and an average-size (1,200-sq $\mathrm{ft}$ ) single-family residence were studied. Each system includes solar thermal and solar photovoltaic energy collection equipment with storage provided by a water tank and lead-acid batteries, respectively. The systems supply the energy demanded by four loads: space heating, space cooling, domestic hot water; and diversified electric requirements (e.g., lighting, electrical appliances). Auxiliary thermal and electric energy supplement solar energy when necessary.

1. Direct Solar Heating and Vapor-Compression Air Conditioning In this simplest system (Fig. 1), collected thermal energy (hot water) is transferred to the storage tank from where it is drawn for space heating and domestic purposes. Convective space heating is accomplished by 
circulating the hot water through finned baseboard pipes and returning it to storage at $21^{\circ} \mathrm{C}$, the desired room temperature.

Collected electrical energy, stored in batteries, passes through an inverter to the diversified electrical load and air conditioning unit. The air conditioning unit absorbs thermal energy from room air and rejects it outdoors. Its electrical input, a function of the amount of cooling it must provide, represents an electrical load in addition to the diversified demand.

Auxiliary electrical power (from a utility) and thermal energy

(from an oil or gas burning heater) are provided when the storage tank or batteries are depleted.

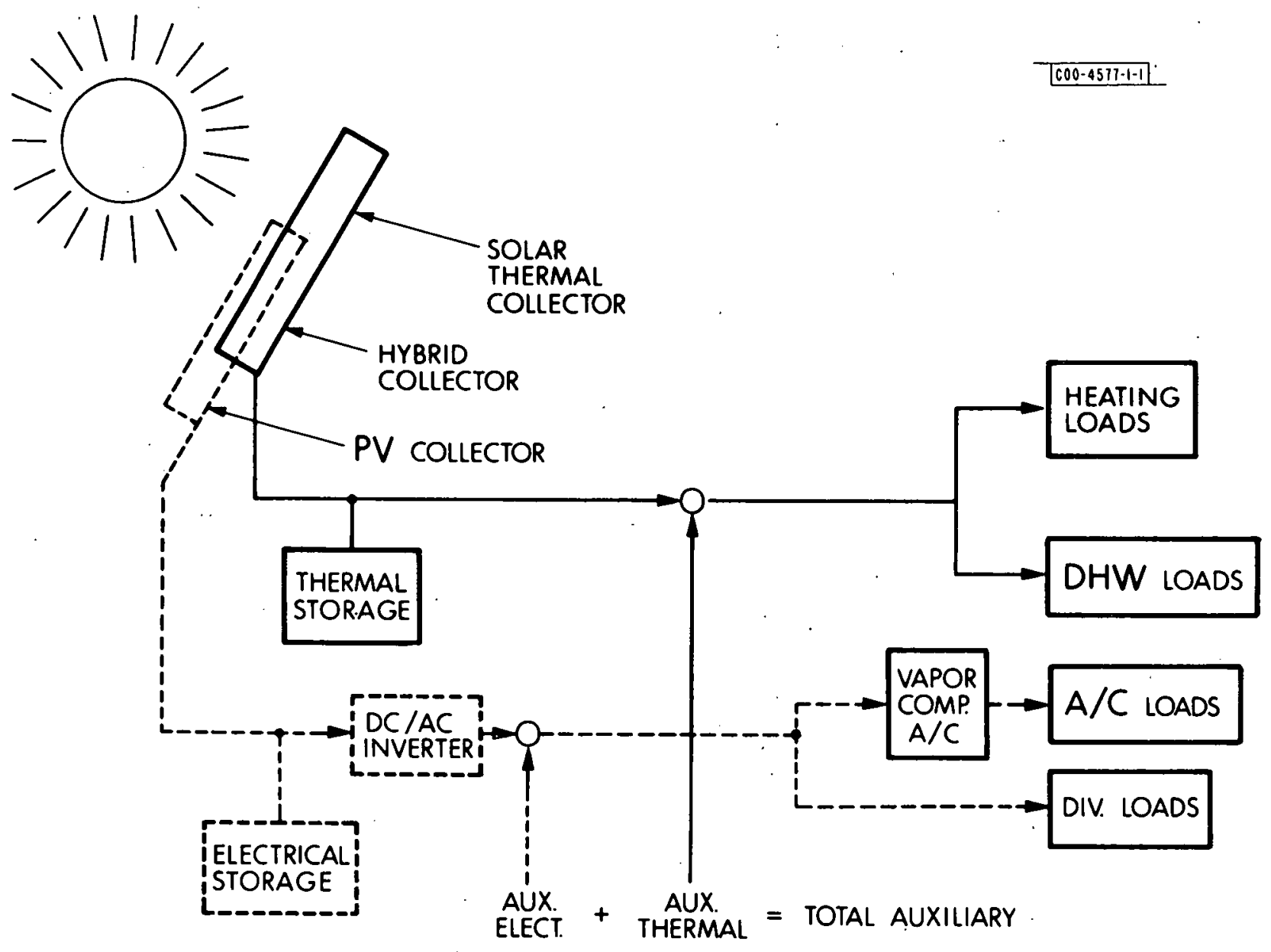

Fig. 1. Baseline hybrid solar power system. 


\section{Parallel Heat Pump}

In this system, space heating and domestic hot water requirements are again met by the collectors and thermal storage. Auxiliary thermal energy, however, is provided by a heat pump operating with an ambient air heat source (Fig. 2). This machine uses the energy available in the outdoor air to supply thermal energy to both the space. heating and domestic hot water demands. Similarly, the heat pump in the cooling mode functions as a vapor-compression air conditioner rejecting heat to the outdoors. Auxiliary electrical energy is supplied as necessary to the heat pump in both the heating and cooling modes as well as to the diversified load.

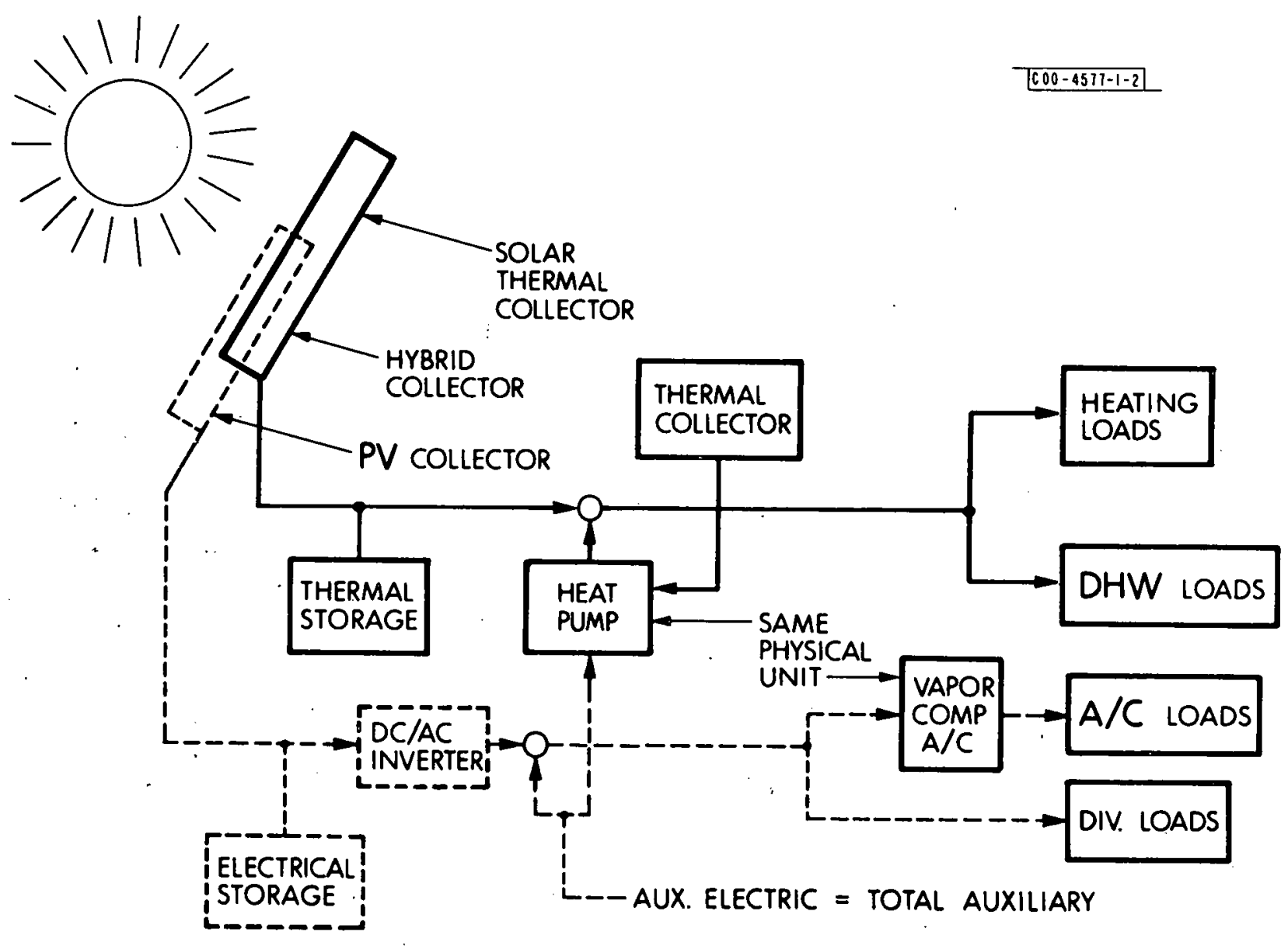

Fig. 2. Parallel heat pump hybrid solar power system. 


\section{Series Heat Pump}

This system uses a heat pump to provide thermal energy to the space heating and domestic hot water requirements (Fig. 3). The collected solar thermal energy in the storage tank is used as the thermal energy source for the heat pump, which is bypassed if thermal collectors and thermal storage, operating alone, can supply the entire domestic hot water and space heating loads. The heat pump is also used to meet the cooling demand by absorbing thermal energy from interior space and rejecting it to outdoor ambient air. Stored electrical energy is provided to the heat pump and diversified load and is supplemented by auxiliary energy.

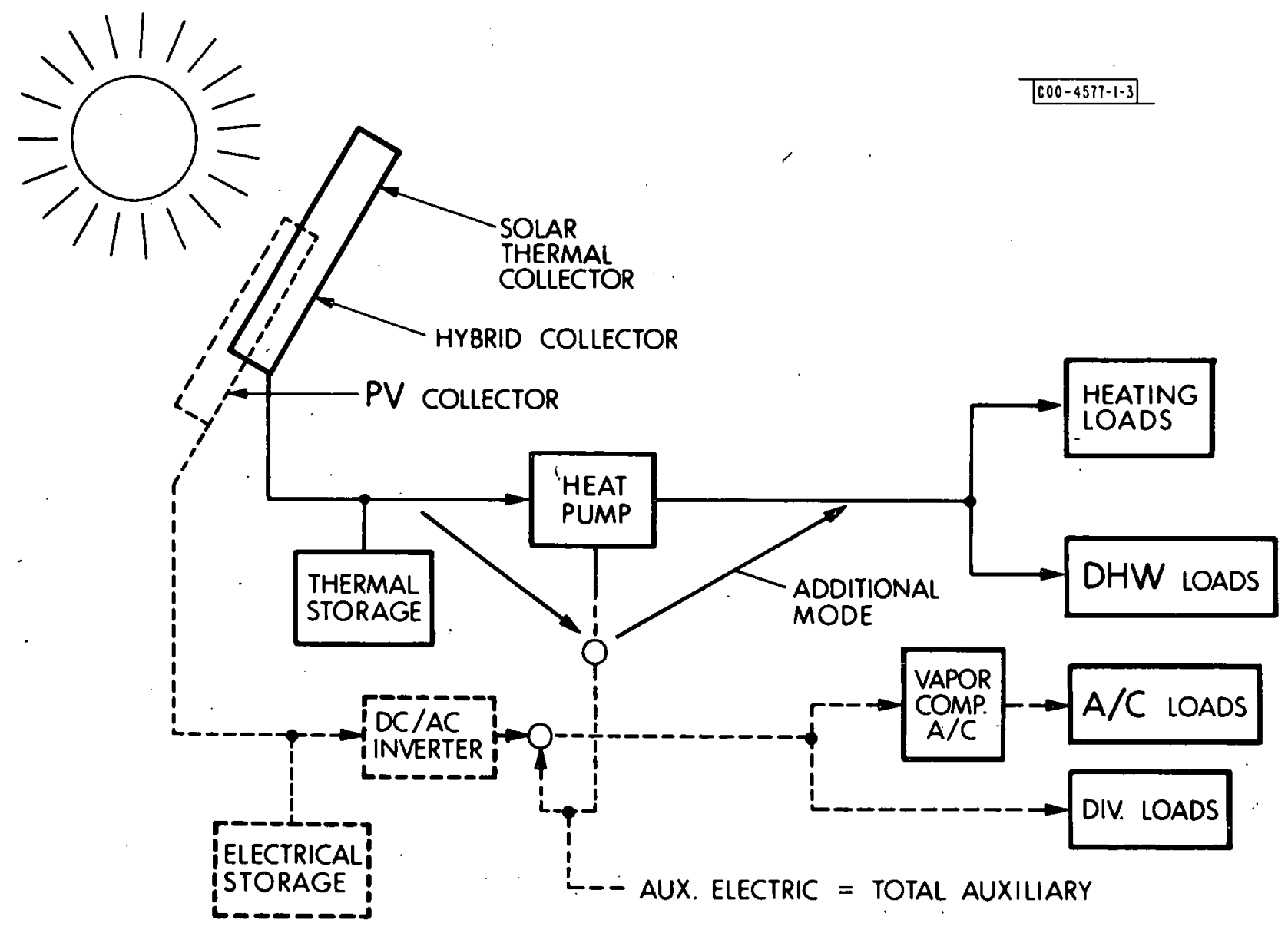

Fig. 3: Series heat pump hybrid solar power system. 


\section{Absorption Air Chiller}

An absorption machine uses thermal energy to provide a cooling effect. This system uses the absorption machine to meet the air conditioning load by providing it with thermal energy from the storage tank (Fig. 4). When no cooling is required this is a direct solar-heating system whereby thermal storage meets the space heating and domestic hot water requirements. When space cooling is necessary, thermal storage supplies the energy required to operate the absorption machine and to meet the domestic hot water demand. Auxiliary thermal energy is provided when the storage tank is depleted. The collected electrical energy supplies the diversified electrical load.

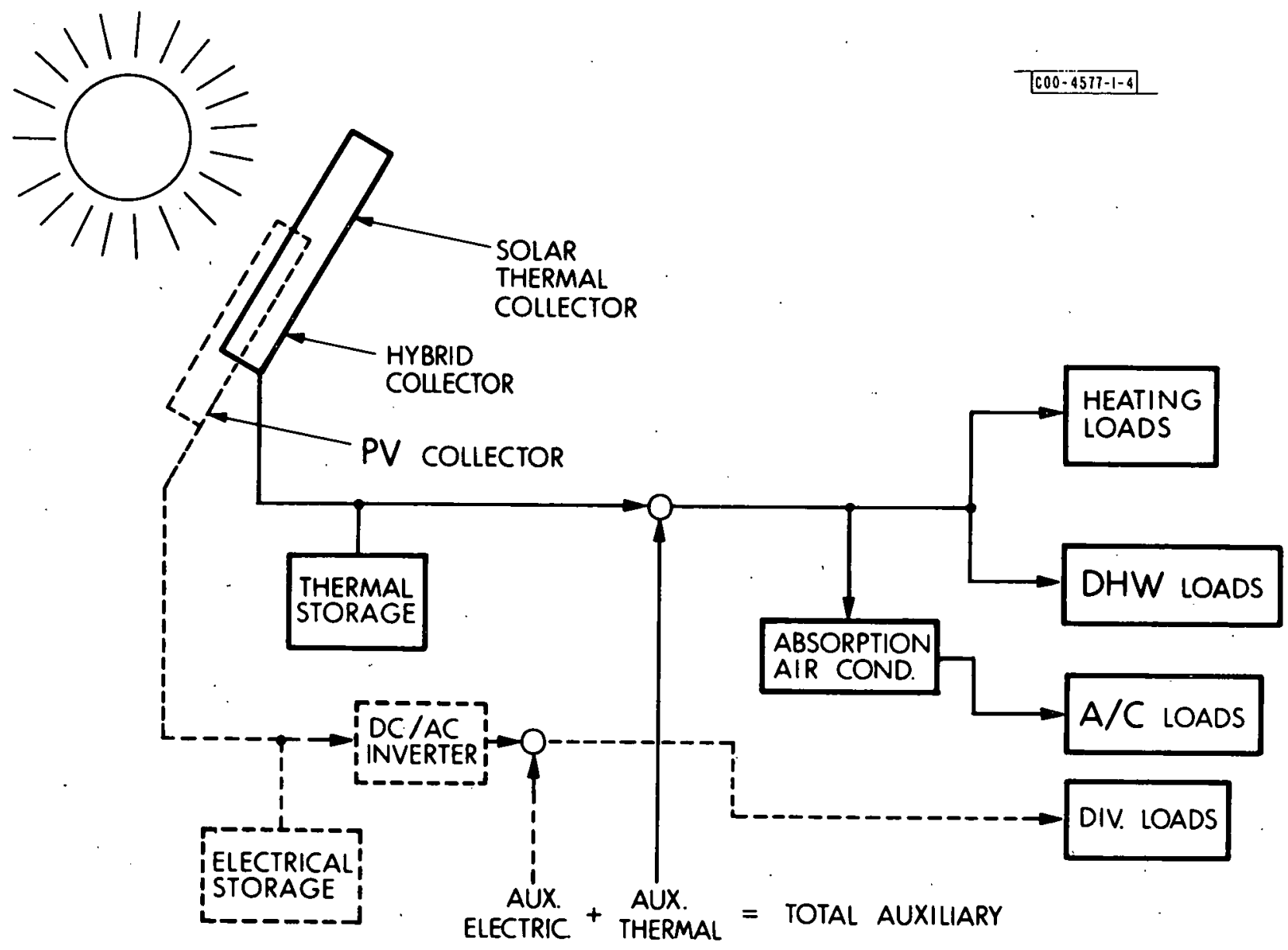

Fig. 4. Absorption cooling hybrid solar power system. 


\section{Series Advanced Heat Pump}

In a series configuration, a high-performance heat pump uses collected thermal energy as its energy source (Fig. 5). The heat pump requires a source temperature of at least $4.44^{\circ} \mathrm{C}$. Auxiliary thermal energy is supplied to maintain the minimum source temperature if storage is depleted. If the collectors and storage alone can meet domestic hot water and space-heating loads, the heat pump is bypassed. In the cooling mode, the heat pump uses thermal energy to run a Rankine-cycle heat engine that drives a vapor-compression air conditioner. Thermal auxiliary is provided the heat pump in the heating mode as required. Collected electrical energy meets the diversified load and the heat pump's electrical demand. Auxiliary electric is provided as necessary.

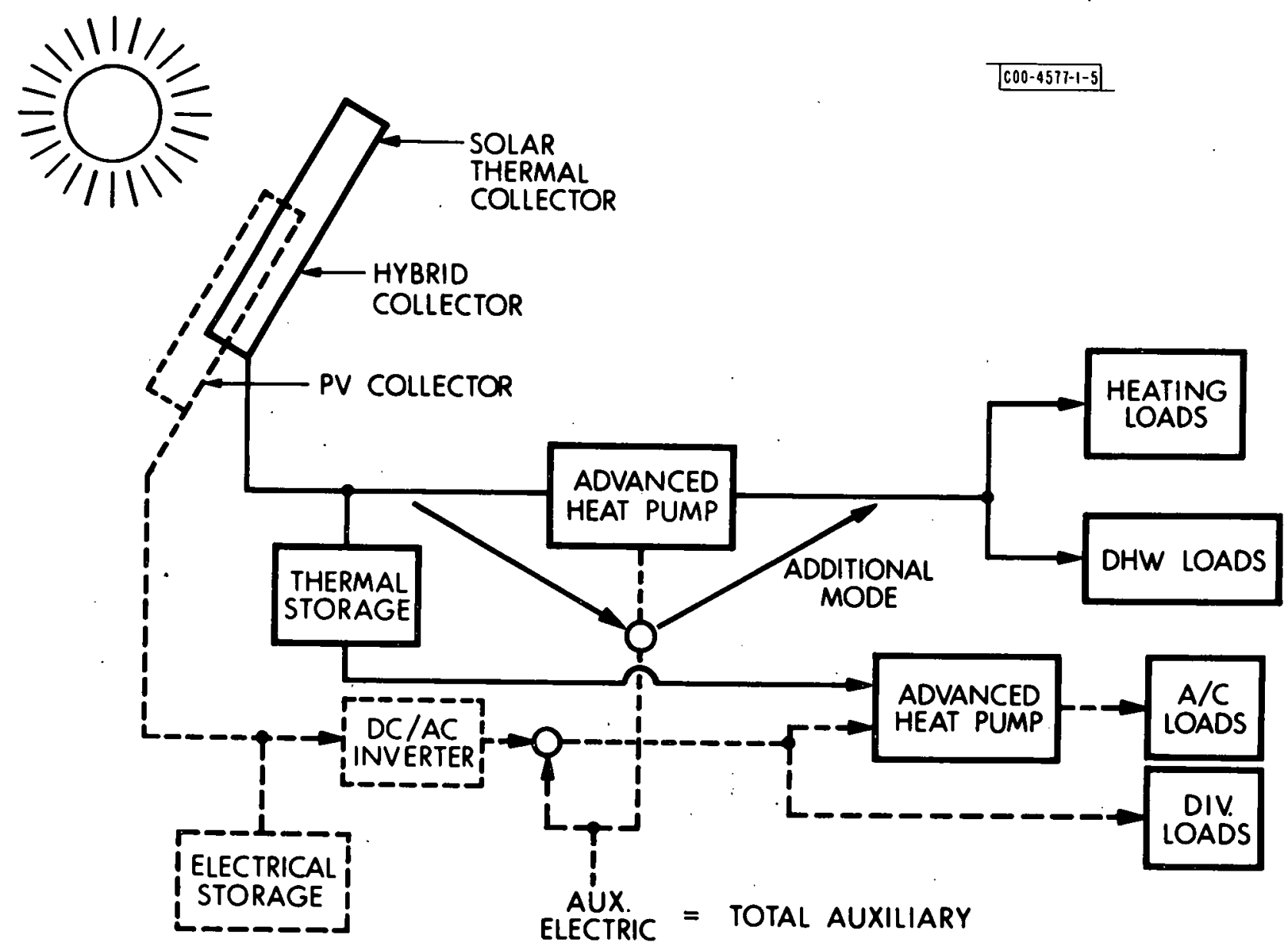

Fig. 5. Series advanced heat pump hybrid solar power system. 


\section{Conventional System}

In a conventional (non-solar) system, included for comparison purposes, heating is provided by an oil or gas burning furnace and cooling by a central vapor-compression air conditioner. Electric demands are supplied by utility power.

\section{Climatic Regions}

Weather conditions for four diverse geographic locationsPhoenix, Ariz.; Miami, Fla.; Boston, Mass.; Ft. Worth, Tex.-were used to evaluate the performance of the heating/cooling systems. These locations provide a suitable range of heating and cooling degree days, ${ }^{*}$ relative humidity, and insolation (Table 1). Each of these cities has a National weather Service SOLMET ${ }^{+}$station recording hourly weather data including direct solar insolation. Also, previous studies that involve solar heating and cooling simulations in these areas are available to provide information on typical heating and cooling loads for a residence and office building.

TABLE 1

CLIMATIC CONDITIONS

\begin{tabular}{|c|c|c|c|c|}
\hline & Phoenix & Miami & Boston & Fort Worth \\
\hline Degree Days-Heating & 1552 & 206 & 5621 & 2382 \\
\hline Degree Days-Cooling & 3508 & 4038 & 661 & 2587 \\
\hline $\begin{array}{l}\text { Annual Range of } \\
\text { Monthly Average } \\
\text { Temperatures }\end{array}$ & $51-91$ & $67-83$ & $29-73$ & $45-85$ \\
\hline $\begin{array}{l}\text { Annual Average } \\
\text { Relative Humidity }\end{array}$ & 42 & 76 & 67 & 63 \\
\hline $\begin{array}{l}\text { Mean Daj.ly Insolation } \\
\left(\mathrm{kWh} / \mathrm{m}^{2} \text { day }\right)\end{array}$ & 6.05 & 5.25 & 3.50 & 5.18 \\
\hline
\end{tabular}

* A heating degree day accrues for every degree the average ambient temperature is below $65 \mathrm{~F}$ for a 24 -hour period. Similarly, cooling degree days accrue when the average ambient temperature is above $65{ }^{\circ} \mathrm{F}$.

+ Solar Meteorological. 
ANALYTIC APPROACHES

Average Performance Model (APM)

The APM program was developed to calculate the amount of auxiliary energy that is required for a solar heating/cooling system to meet the total energy demand of an office building or residence. The amount of usable solar energy collected, both thermal and photovoltaic, depends on the insolation available and the collector efficiency-a linear function of the collector temperature.

The collector temperature (an independent variable for hybrid or solar thermal collectors) was determined by calculating the temperature at which no excess thermal energy was collected. Figure 6 shows, for example, the amount of energy required to raise the temperature of the mass of water required for domestic uses from ground-water temperature to the collection temperature $\left(\mathrm{T}_{\mathrm{C}}\right)$. This energy requirement is given by:

$$
\mathrm{Q}=\mathrm{mC}_{\mathrm{p}}\left(\mathrm{T}_{\mathrm{c}}-\mathrm{T}_{\mathrm{gW}}\right)
$$

where $Q=$ energy required

$\mathrm{m}=$ mass of water to be heated

$\mathrm{C}_{\mathrm{p}}=$ specific heat of water

$\mathrm{T}_{\mathrm{C}}^{\mathrm{p}}=$ collection temperature

$\mathrm{T}_{\mathrm{gw}}=$ ground-water temperature.

The second curve shows the amount of solar energy collected for a given array area at $\mathrm{T}_{\mathrm{C}}$. The temperature for collection was chosen at the intersection of these curves. This temperature corresponds with the smallest amount of auxiliary energy required.

In this model, monthly average values were determined for the following climatic quantities:
a. Daytime ambient dry bulb temperature
$\left({ }^{\mathrm{O}} \mathrm{C}\right)$
b. Nighttime ambient dry bulb temperature
c. Daily ambient wet bulb temperature.
$\left({ }^{\circ} \mathrm{C}\right)$
d. Insolation energy
$\left(\mathrm{kWh} / \mathrm{m}^{2}\right.$-day)
e. Day length
(hr/day) 
$\begin{array}{ll}\left.\text { f. Insolation power ( } \frac{\text { insolation energy }}{\text { day length }}\right) & \left(\mathrm{kW} / \mathrm{m}^{2}\right) \\ \text { g. ground-water temperature } & \left({ }^{\circ} \mathrm{C}\right)\end{array}$

For each application and geographic location the total area used to collect energy was kept constant, but the fraction of that area filled by any one type of collector varied. Any point on the shaded surface (Fig. 7a) represents a possible array comprised of three types of collectors. Analysis reveals that the most energy-productive collector combinations lie along the highlighted borders of the triangular surface. Consequently, collector-area fractions were varied from 0-100 percent photovoltaic (or thermal) collectors with the remainder of the array area always filled by hybrid collectors. The total auxiliary energy required (electric plus thermal) was calculated for each collector-area combination as in Fig. $7 \mathrm{~b}$.

A flowchart of the program is shown in Fig. 8 .

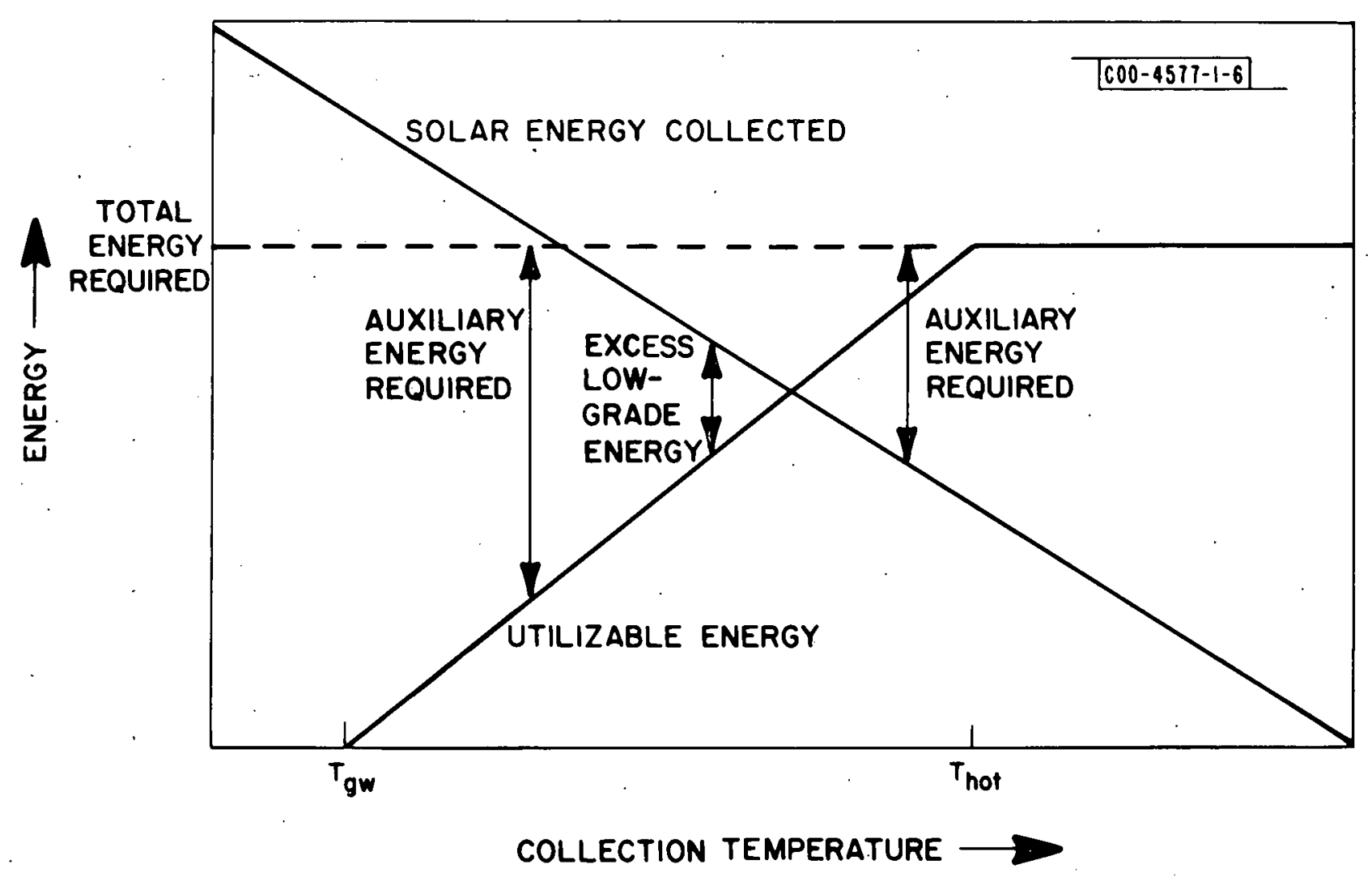

Fig. 6. Energy vs. collection temperature. 
(a)

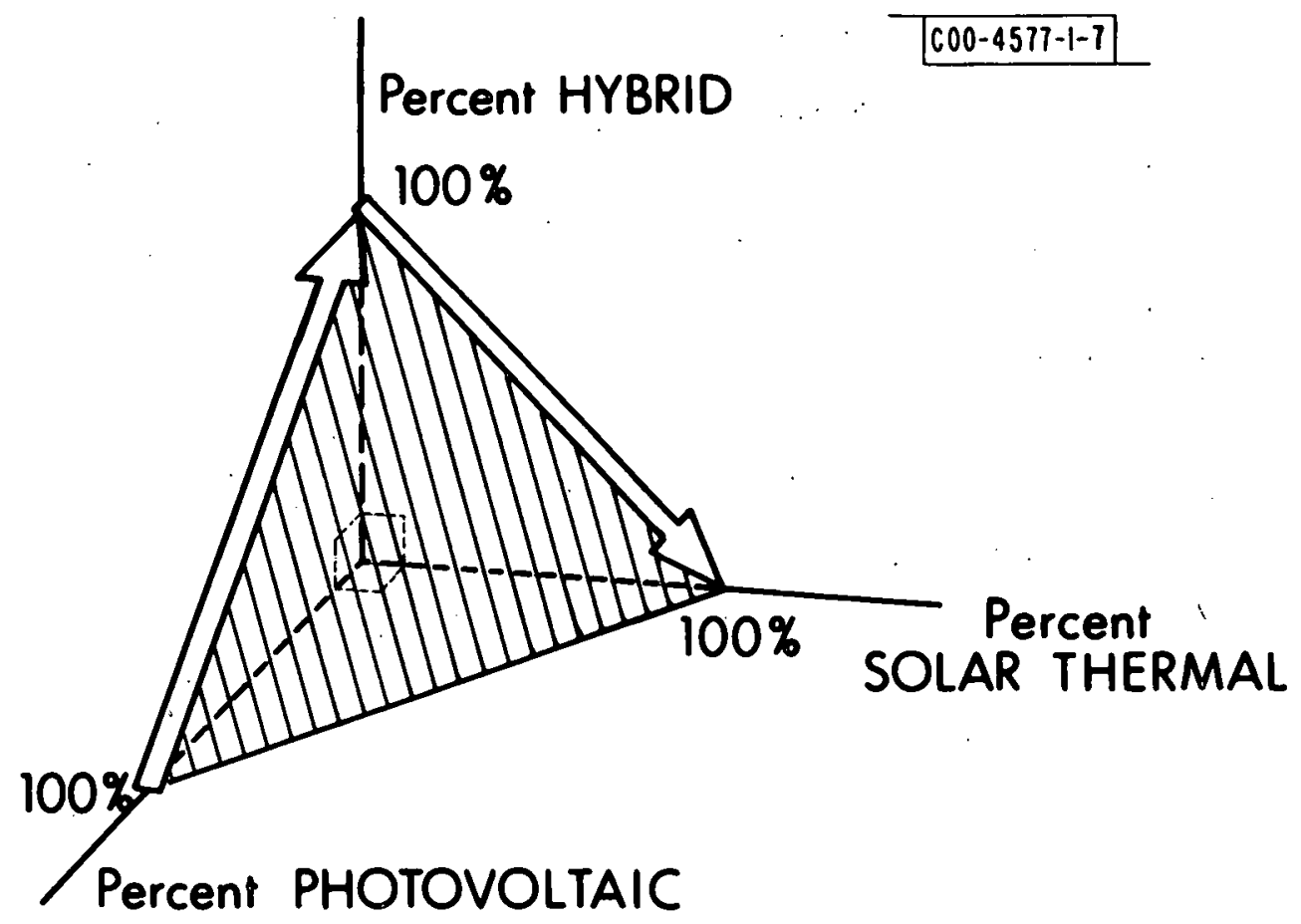

(b) Energy

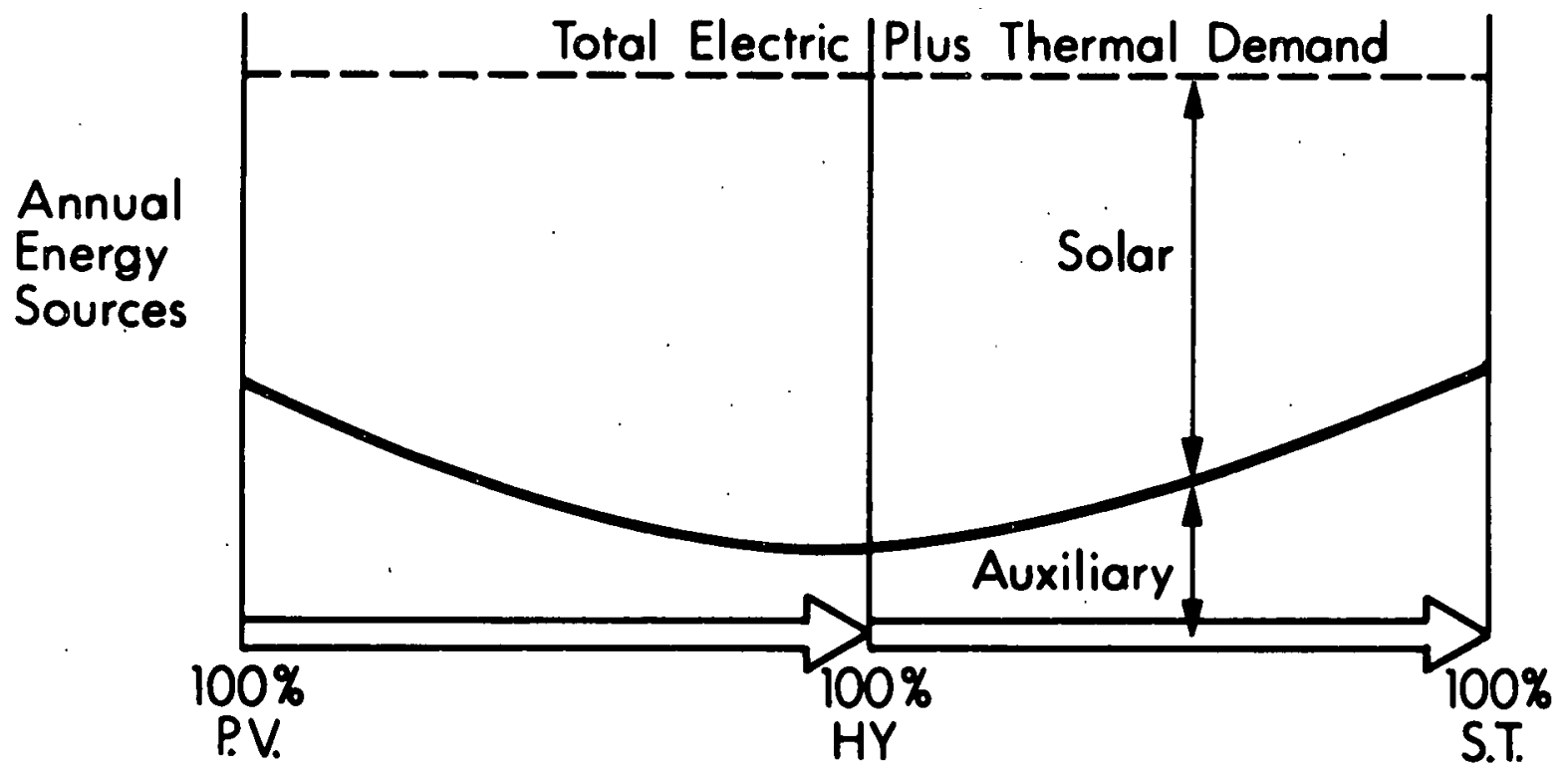

Fig. 7. Technical performance of the average performance model. 


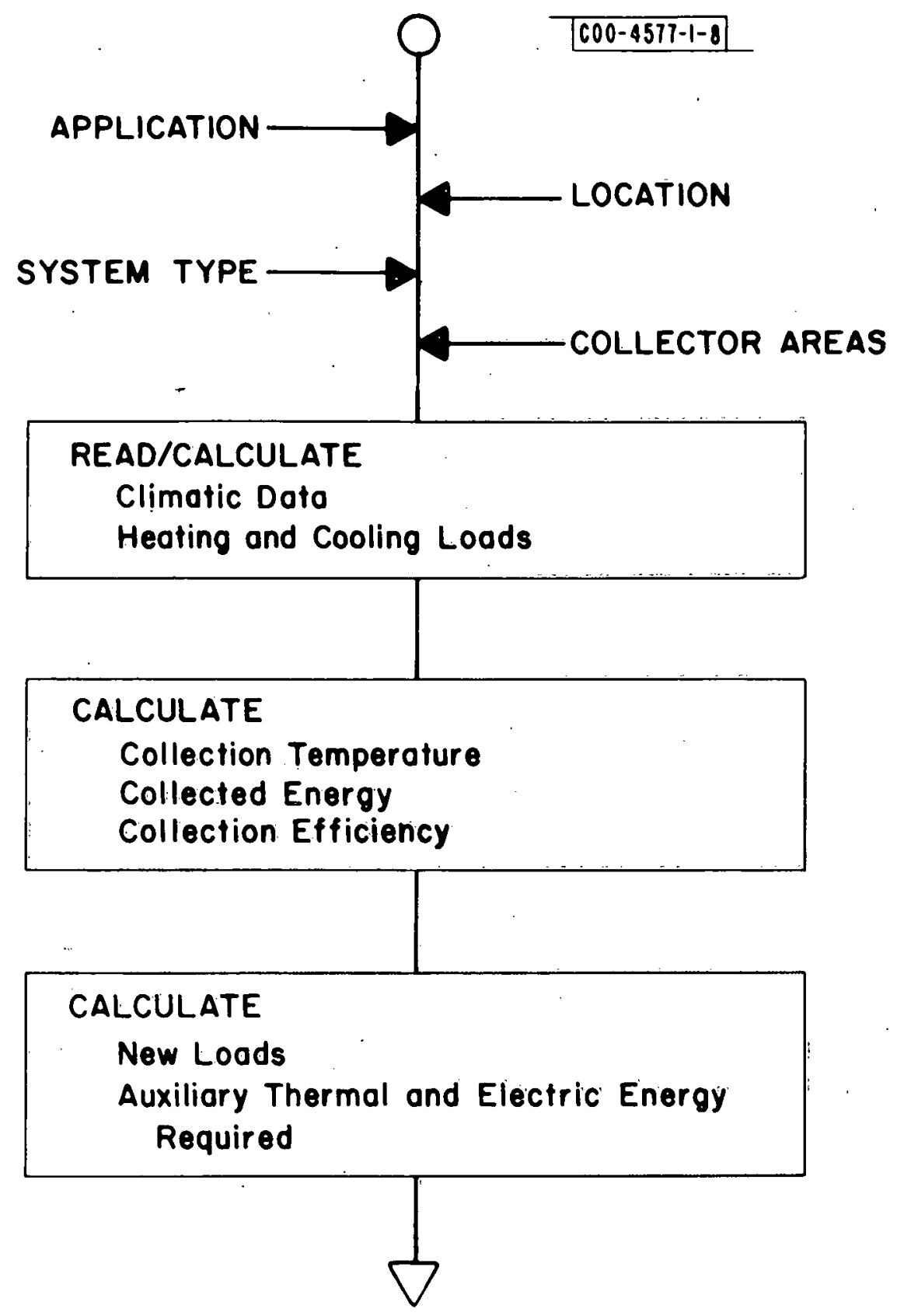

Fig. 8. Average performance model. 
The mathematical models for the system components are:

Components

1. Collectors

Three types of collectors were considered: hybrid, thermal, and photovoltaic. Expressions for collector efficiency as a function of collector temperature were obtained for a single-glazed thermal collector and an available solar cell module. A hybrid model was synthesized from a combination of these two.

To study future time-frame cases it was necessary to adjust the photovoltaic and hybrid collector efficiencies according to the estimates for projected increased photovoltaic efficiencies. The resulting expressions used were:

Hybrid

Photovoltaic

Thermal

$$
\begin{aligned}
& \eta_{h e}=0.0634-0.0003\left(\mathrm{~T}_{\mathrm{c}}\right) \\
& \eta_{\text {he }}=0.0912-0.0004\left(\mathrm{~T}_{\mathrm{C}}\right) \\
& \eta_{h \mathrm{he}}=0.1140-0.0005\left(\mathrm{~T}_{\mathrm{c}}\right) \\
& \eta_{h t}=0.6816-0.0056\left(\mathrm{~T}_{\mathrm{C}}-\mathrm{TDD}\right) / \mathrm{PI} \\
& \eta_{h t}=0.6588-0.0055\left(\mathrm{~T}_{\mathrm{C}}-\mathrm{TDD}\right) / \mathrm{PI} \\
& \eta_{h t}=0.6860-0.0054\left(\mathrm{~T}_{\mathrm{c}}-\mathrm{TDD}\right) / \mathrm{PI}
\end{aligned}
$$

$$
\mathrm{T}_{\mathrm{o}}=\mathrm{TDD}+3.13 \times 10^{-5}(\mathrm{PI})
$$

$$
\begin{aligned}
& \eta_{p v}=0.0684-0.0003\left(\mathrm{~T}_{\mathrm{o}}\right) \\
& \eta_{\mathrm{pv}}=0.0912-0.0004\left(\mathrm{~T}_{\mathrm{o}}\right) \\
& \eta_{\mathrm{pv}}=0.1140-0.0005\left(\mathrm{~T}_{\mathrm{o}}\right)
\end{aligned}
$$

where $\eta_{\text {he }}=$ electrical efficiency of hybrid collector

$$
\eta_{t}=0.75-0.0059\left(\mathrm{~T}_{\mathrm{c}}-\mathrm{TDD}\right) / \mathrm{PI}
$$

$n_{h t}=$ thermal efficiency of hybrid collector

$n_{t}=$ efficiency of thermal collector

$n_{p v}=$ efficiency of photovoltaic collector

$\mathrm{T}_{\mathrm{O}}=$ operating temperature of photovoltaic collector $\left({ }^{\circ} \mathrm{C}\right)$ 
$\mathrm{TDD}=$ daytime ambient dry bulb temperature $\left({ }^{\circ} \mathrm{C}\right)$

$\mathrm{T}_{\mathrm{C}}=$ collector temperature (hybrid or therma1) $\left({ }^{\circ} \mathrm{C}\right)$

$\mathrm{PI}=$ insolation power $\left(\mathrm{kW} / \mathrm{m}^{2}\right)$.

2. Standard Heat Pump

A heat pump was characterized by its coefficient of performance (COP), which is the ratio of thermal energy supplied to the load (or in the cooling mode, thermal energy absorbed) to electrical energy input to the compressor. A linear approximation for COP as a function of therma1-energy source temperature (or in the cooling mode, sink temperature) was used for both the heating and cooling modes:

$$
\begin{aligned}
& \mathrm{COPH}=2.01+0.06 \mathrm{~T}_{\mathrm{S}} \\
& \mathrm{COPC}=4.71-0.06 \mathrm{~T}_{\text {sk }}
\end{aligned}
$$

where $T_{S}=$ source temperature $\left({ }^{\circ} \mathrm{C}\right)$

$\mathrm{T}_{\text {sk }}=$ sink temperature $\left({ }^{\circ} \mathrm{C}\right)$

$\mathrm{COPH}=$ heating mode $\mathrm{COP}$

$\mathrm{COPC}=$ cooling mode $\mathrm{COP}$

The electrical energy requirement for a heat pump is:

$$
Q_{e}=Q_{\text {load }} / \text { COP }
$$

where $Q_{e}=$ electric energy required by heat pump (kW)

$$
\mathrm{Q}_{\text {load }}=\text { thermal heating or cooling load }(\mathrm{kW})
$$

\section{Vapor-Compression Air Conditioner}

A vapor-compression air conditioner was modeled the same as a heat pump in the cooling mode and the same expressions for COP and electrical energy requirement were used.

\section{Advanced Heat Pump}

The advanced heat pump in the heating mode is a high-performance device designed to run in a series solar-assisted configuration. Its heating $\mathrm{COP}$ is given by:

$$
\mathrm{COPH}=2.9054+0.02326 \mathrm{~T}_{\mathrm{S}}+0.004957 \mathrm{~T}_{\mathrm{S}}^{2} .
$$


This machine reaches a maximum allowable compressor speed when the source temperature drops to $4.44^{\circ} \mathrm{C}$. Therefore, for it to operate,

$$
\mathrm{T}_{\mathrm{C}} \geq 4.44^{\circ} \mathrm{C} \text {. }
$$

In the cooling mode, the machine uses thermal energy to power a Rankine-cycle heat engine that drives a vapor-compression air conditioning system. The thermal-energy source temperature must be above $66^{\circ} \mathrm{C}$ to operate the Rankine cycle. The cooling mode COP is:

$$
\begin{aligned}
\text { COPC }= & 3.97-0.120 \mathrm{~T}_{w b}-\left[0.0155-5.36 \times 10^{-4} \mathrm{~T}_{w b}\right] \\
& {\left[1.8 \mathrm{~T}_{\mathrm{S}}+32.0\right] }
\end{aligned}
$$

where $\mathrm{T}_{\mathrm{wb}}=$ ambient wet bulb temperature $\left({ }^{\circ} \mathrm{C}\right)$

$$
\mathrm{T}_{\mathrm{S}} \geq 66^{\circ} \mathrm{C} \text {. }
$$

If the source temperature drops below $66^{\circ} \mathrm{C}$, an auxiliary electric motor drives the vapor-compression cooling system. In this case,

$$
\mathrm{COPC}=5.84-0.065 \mathrm{~T}_{\mathrm{wb}} \quad .
$$

5. Absorption Chiller

An absorption chiller was also characterized by a COP defined as the ratio of thermal energy absorbed (cooling effect) to thermal energy input. For this device the cooling $\mathrm{COP}$ is:

$$
\begin{aligned}
\text { COPC } & =-0.25+0.01 \mathrm{~T}_{S} \\
Q_{\text {th }} & =Q_{1 \text { oad }} / \text { COPC }
\end{aligned}
$$

where $Q_{\text {th }}=$ thermal energy input at temperature $T_{S}$.

The source temperature must be above $74^{\circ} \mathrm{C}$ for the absorption cycle to operate.

Each of these component models was used in both the APM and the detailed simulation.

DETAILED SIMULATION

A computer program being developed by MIT/LL will evaluate the time-varying performance of hybrid, solar-thermal, and solar-photovoltaic energy systems. At present, the model can simulate the thermal and electrical behavior of a thermostatically controlled residence. 


\section{Solar-Thermal Subsystem}

The program models the solar-thermal subsystem (Fig. 9) with two "capacitive" elements that represent the thermal-energy storage and the house. Numerous "resistive" elements are modeled to account for heat flows due to temperature differences across walls, windows, etc.

The time-varying house temperature, $\mathrm{T}_{\mathrm{h}}$, and thermal-storage temperature, $T_{t}$, were calculated incrementally for a Boston location according to:

$$
\begin{aligned}
& \Delta T_{h}=\frac{1}{C_{h}} F_{h}\left(q_{h}, T_{h} ; Q_{s w}, T_{a}\right) \Delta t \\
& \Delta T_{t}=\frac{1}{C_{t}} F_{t}\left(q_{t}, T_{t}, q_{w}, n_{e} ; Q_{s}, T_{a}\right) \Delta t
\end{aligned}
$$

where $Q_{S}$ and $Q_{S W}$ are the input energy flow rates through the solar (thermal) array and windows, respectively, and $\mathrm{T}_{\mathrm{a}}$ is the ambient temperature. Also:

$C_{h}=$ thermal capacity of the house

- $C_{t}=$ thermal capacity of the storage

$q_{h}=$ energy flow into (or, in cooling mode, out of) the house

$q_{t}=$ energy flow out of the storage tank

$n_{e}=$ electrical efficiency of the hybrid or PV collectors.

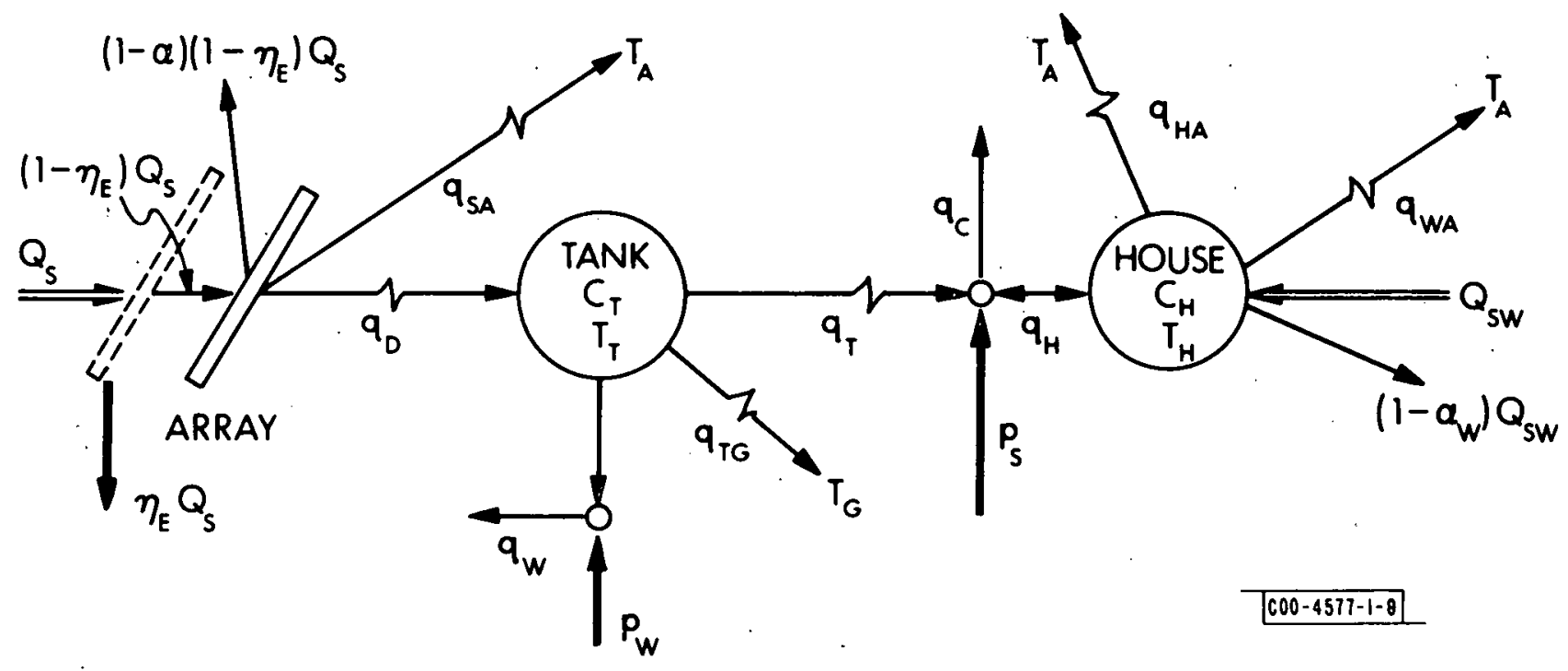

Fig. 9. Solar-thermal subsystem. 
These two equations are coupled through $\mathrm{q}_{h}$ and $\mathrm{q}_{t}$ according to:

$$
q_{h}=q_{t}+p_{s}-q_{c}
$$

where $P_{S}$ is the supplementary energy required, if any, to maintain the house at the prescribed temperature. $P_{S}$ is applied in different ways depending on the season of the year and the type of heating and cooling hardware used. $q_{c}$ represents the thermal energy removed from the house when the system is operating in the cooling mode and $\mathrm{P}_{\mathrm{S}}$ is the electrical energy required to power the vapor-compression air conditioner either alone or when advanced heat pump hardware is used in conjunction with a Rankine-cycle turbine. The turbine is powered by the thermal energy in storage. In the heating mode, $\mathrm{P}_{\mathrm{S}}$ is the electrical energy required to heat the domestic or space-heating water resistively, if a heat pump is not used.

Referring again to Eqs. $(23,24), \mathrm{q}_{\mathrm{w}}$ is the energy taken from thermal storage to meet the hot-water demand. In approximating the behavior of hot-water systems, $q_{w}$ is assumed constant throughout any month and variations from month to month reflect changes in the ground-water temperature, $\mathrm{T}_{\mathrm{g}}$. If the thermal-storage temperature, $\mathrm{T}_{t}$, drops below $48.9^{\circ} \mathrm{C}$, then electric power, $\mathrm{P}_{\mathrm{W}}$, is used to meet the demand.

The photovoltaic subsystem provides the electric power, $\mathrm{P}_{\mathrm{S}}+\mathrm{P}_{\mathrm{W}}$, as needed.

\section{Solar-Photovoltaic Subsystem}

A maximum power tracker ${ }^{*}$ is used to obtain the greatest amount of energy from the photovoltaics. The operating voltage level of the photovoltaic array is assumed to be converted to match the storage-battery voltage. Power from the array, $P_{a}$, charges the batteries if it exceeds the amount required to carry the load, $\mathrm{P}_{1}$. An inverter to convert $\mathrm{DC}$ to $\mathrm{AC}$ is assumed to be 85 -percent efficient (Fig. 10).

* A maximum power tracker senses the power output of the photovoltaic array and continuously adjusts the operating voltage of the array to achieve the maximum output power. 


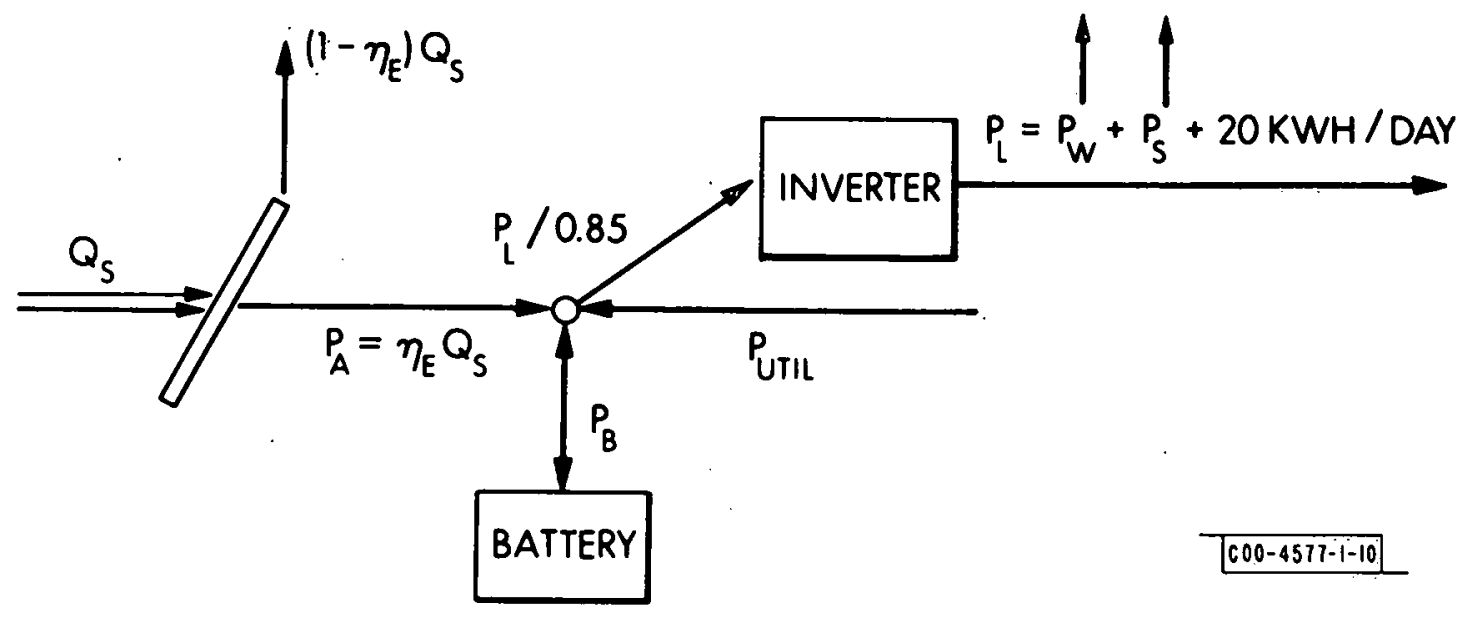

Fig. 10. Solar-electric subsystem.

If the state-of-charge of the battery ${ }^{*}$ drops below a prescribed value (20 percent) utility power comes on-line to recharge the battery and help carry the load. Once the battery state-of-charge has reached another prescribed level (30 percent) the utility is taken off-line.

The electrical load consists of a $20-\mathrm{kWh} /$ day diversified component together with whatever is required for heating and cooling; i.e., $\mathrm{P}_{\mathrm{S}}+\mathrm{P}_{\mathrm{W}}$ :

\section{Methods Comparison}

The total auxiliary energy required for a Boston residence as determined by the APM was compared with that obtained by the detailed simulation to check the accuracy of the APM for four systems (Table 2):

1. Direct solar heating and vapor-compression air conditioning

2. Parallel heat pump

3. Series heat pump

4. Series advanced heat pump.

*

Battery state-of-charge is measured by. the integral over time of current in and out of the battery with energy losses due to differences in battery charge and discharge characteristics taken into account. 
TABLE 2

METHODS COMPARISON

(Total Auxiliary Energy Required by Boston Residence)

\begin{tabular}{|c||r|c|c||c|c|c|}
\hline \multicolumn{1}{|c||}{} & \multicolumn{3}{|c|}{ Total Auxiliary Energy } & \multicolumn{3}{c|}{ Solar Fraction } \\
\cline { 2 - 6 } System & APM & $\begin{array}{c}\text { Detailed } \\
\text { Simulation }\end{array}$ & $\Delta \%$ & APM & $\begin{array}{c}\text { Detailed } \\
\text { Simulation }\end{array}$ & $\Delta \%$ \\
\hline 1 & 14.15 & 12.97 & +9.1 & 0.58 & 0.62 & -6.5 \\
2 & 9.50 & 10.95 & -13.2 & 0.72 & 0.68 & +5.9 \\
3 & 10.76 & 10.54 & +2.1 & 0.68 & 0.69 & -1.4 \\
4 & 8.01 & 7.96 & +0.63 & 0.76 & 0.77 & -1.3 \\
\hline
\end{tabular}

The solar fraction, i.e., the fraction of conventional thermal plus electrical load provided by the solar system, was also calculated by the APM and detailed simulation methods for comparison of APM accuracy. Hourly temperatures and insolation for Boston in 1958 were used in the detailed simulation; average monthly values were used by the APM.

The total auxiliary energy required as determined by the APM was within 13.2 percent, and the APM solar fraction within 6.5 percent, of the values calculated by the detailed simulation. Subsequent calculations were made using the APM to minimize computer time while maintaining reasonable accuracy.

ECONOMIC ANALYSES

The total annual system costs for the five different systems for $1986^{*}$ were evaluated and compared. Total annual system cost consisted of three separate costs:
a. System components
b. Auxiliary energy
c. Operation/maintenance.

$*$

Evaluations were made for 1986 since research efforts are aimed at showing the viability of photovoltaic energy sources by that year. 
The initial cost, salvage value, and expected lifetime estimates were obtained (Table 3) for each system component (collectors, batteries, etc.). A component was assumed to be financed over its lifetime so that the annual payment for a component was:

$$
\mathrm{PMT}=i\left[\operatorname{cst}-\frac{\operatorname{svg}}{(1+i)^{\mathrm{n}}}\right] /\left[1-\frac{1}{(1+i)^{\mathrm{n}}}\right]
$$

Where PMT $=$ Annual payment for a component

$i=$ Annual discount rate

cst $=$ Initial investment for component

svg = Value of component at end of its lifetime

$\mathrm{n}=$ Expected lifetime of component (years)

The total capital cost is the sum of the payments for each component in a system. A discount rate of four percent was used for a residence and ten percent for an office building. Fuel-price escalation rates of . three and six percent were used for two possible escalations of auxiliary energy costs. A levelized price for auxiliary energy was determined by calculating the present value of predicted escalating energy prices and then distributing this value as a levelized series of payments.

The annual operation and maintenance cost for system components was assumed to be 1.5 percent of the initial investment.

\section{CONCLUSIONS}

\section{Technical Performance Results}

Results of the APM (Figs. 11-12) reflect auxiliary energy calculations using 1986 collector efficiencies. The most significant energy savings achieved (compared to the conventional energy requirement) are provided by the advanced heat pump system for all four locations for both the residence and office building.

The absorption air conditioner system showed energy-savings promise in regions of low humidity dominated by a cooling load (Fig. 1la) but not in areas of high humidity or low cooling loads (Figs. 11b, 11c, 12b, 12c). The minimum auxiliary energy required for all five systems in 
TABLE 3

COMPONENTS COST

\begin{tabular}{|c|c|c|c|}
\hline Components & 1977 & 1986 & Comments \\
\hline Photovol taic modules 1,2 & $\begin{array}{r}720 \\
\cdot \quad 0 \\
20\end{array}$ & $\begin{array}{r}75 \\
0 \\
20\end{array}$ & $\begin{array}{ll}\text { Installed cost } & \left(\$ / \mathrm{m}^{2}\right) \\
\text { Salvage } & (\% \text { cost }) \\
\text { Lifetime } & \text { (years) }\end{array}$ \\
\hline Solar-thermal collectors ${ }^{2}$ & $\begin{array}{r}120 \\
0 \\
20\end{array}$ & $\begin{array}{r}70 \\
0 \\
20\end{array}$ & ". \\
\hline Hybrid collectors ${ }^{1}$, & $\begin{array}{r}890 \\
0 \\
20\end{array}$ & $\begin{array}{r}135 \\
0 \\
20\end{array}$ & " \\
\hline $\mathrm{AC} / \mathrm{DC}$ inverters ${ }^{3}$ & $\begin{array}{r}215 \\
10 \\
20\end{array}$ & $\begin{array}{l}40 \\
10 \\
20\end{array}$ & Installed cost $(\$ / k V a)$ \\
\hline Batteries $^{3}$ & $\begin{array}{r}110 \\
15 \\
7\end{array}$ & $\begin{array}{l}40 \\
15 \\
15\end{array}$ & Installed cost $(\$ / \mathrm{kWh})$ \\
\hline Advanced heat pump ${ }^{4}$ & $\begin{array}{r}10,000 \\
20 \\
20\end{array}$ & $\begin{array}{r}4,000 \\
20 \\
25\end{array}$ & Installed cost $(\$)$ \\
\hline Thermal storage 5 & $\begin{array}{r}15 \\
0 \\
20\end{array}$ & $\begin{array}{r}15 \\
0 \\
20\end{array}$ & Installed cost $\left(\$ / m^{2}\right)$ \\
\hline Absorption air chiller ${ }^{6}$ & $\begin{array}{r}3,200 \\
15 \\
20\end{array}$ & $\begin{array}{r}2,500 \\
15 \\
20\end{array}$ & Installed cost $(\$)$ \\
\hline Standard heat pump ${ }^{7}$ & $\begin{array}{r}2,000 \\
15 \\
20\end{array}$ & $\begin{array}{r}1,500 \\
15 \\
30\end{array}$ & Installed cost $(\$)$ \\
\hline Conventional furnace ${ }^{8}$ & $\begin{array}{r}300 \\
15 \\
25\end{array}$ & $\begin{array}{r}200 \\
15 \\
25\end{array}$ & Installed cost $(\$)$ \\
\hline Central air conditioner ${ }^{9}$ & $\begin{array}{r}1,290 \\
15 \\
20\end{array}$ & $\begin{array}{r}1,290 \\
15 \\
30\end{array}$ & Installed cost (\$) \\
\hline
\end{tabular}

${ }^{1} \mathrm{DOE}$ cost goals: $\$ 12 / \mathrm{W}$ at $6 \%$ area efficiency (1977), $\$ 2 / \mathrm{W}$ at $8 \%$ area efficiency (1980), $\$ 0.50 / \mathrm{W}$ at $10 \%$ area efficiency (1986).

${ }^{2}$ Office of Technology Assessment (OTA), "Application of Solar Technology to Today's Energy Needs" (June 1977), pp. XI-71 to XI-74. OTA, op. cit., p. XI-97.

${ }^{4}$ Garret-AiResearch 1986 projection for advanced heat pump, others approximate. 5 Duffie, Beckman, and Dekker, "Solar Heating in North America," Mechancial Engineering (November 1977), p. 38.

${ }^{6} \mathrm{Arkla}$ Industry's current price for 3 -ton unit, others approximate.

${ }^{7}$ OTA, op. cit., p. XI-17, 3-ton unit.

${ }^{8}$ OTA, op. cit., p. XI-17, approximately 60,000-Btuh unit

${ }^{9}$ OTA, op. cit., p. XI-17, 3-ton unit. 
Boston, where the annual heating load is substantial (Figs. 11b, 12b) can be provided by a mix of collectors that include hybrid collectors.

In geographic locations where the heating requirement is minimal, increased energy savings occur as hybrid collectors are replaced by photovoltaic collectors due to the relatively small demand for thermal energy. 

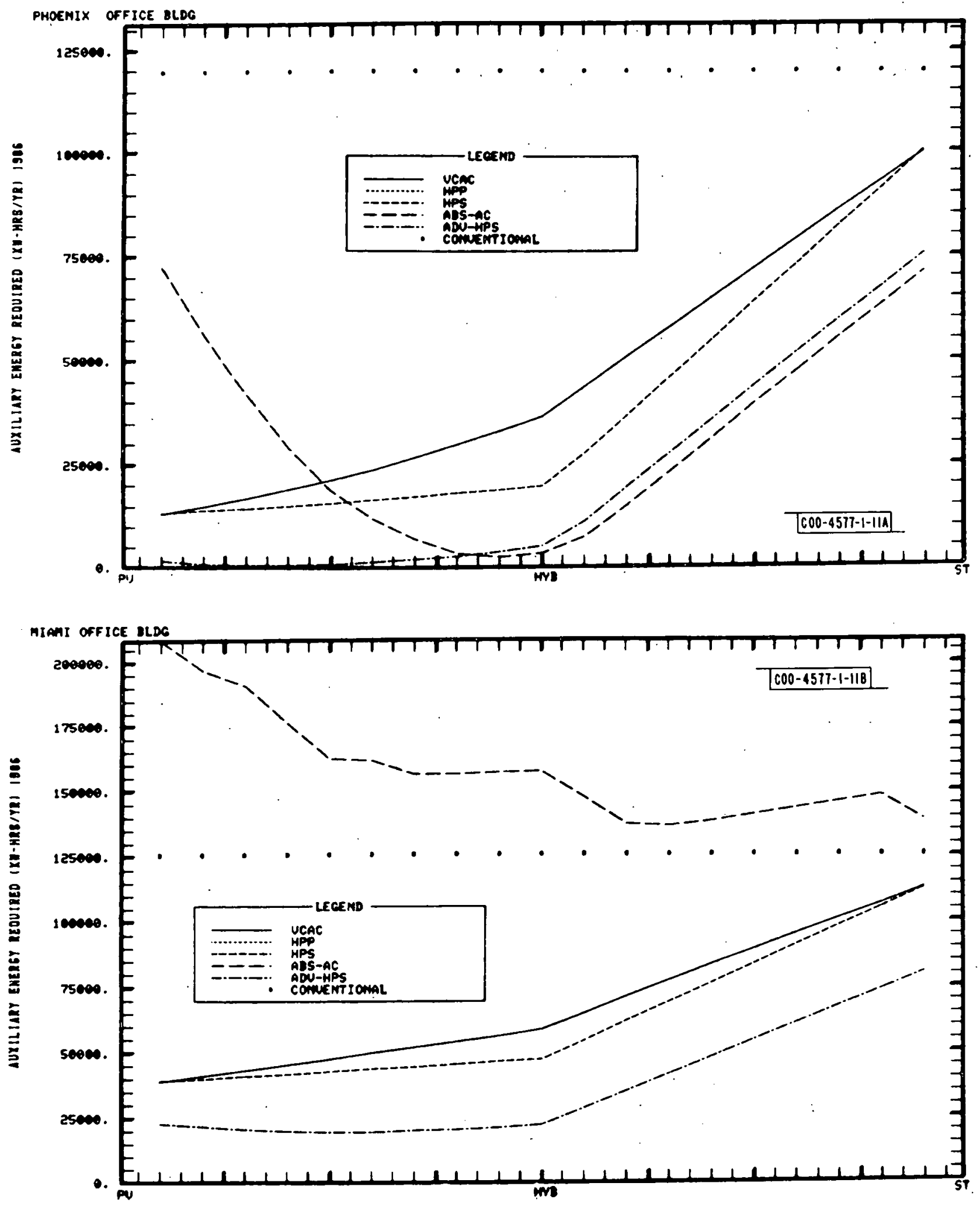

Fig. 1la,b. Auxiliary energy requirement for office building in (a) Phoenix and (b) Miami. 

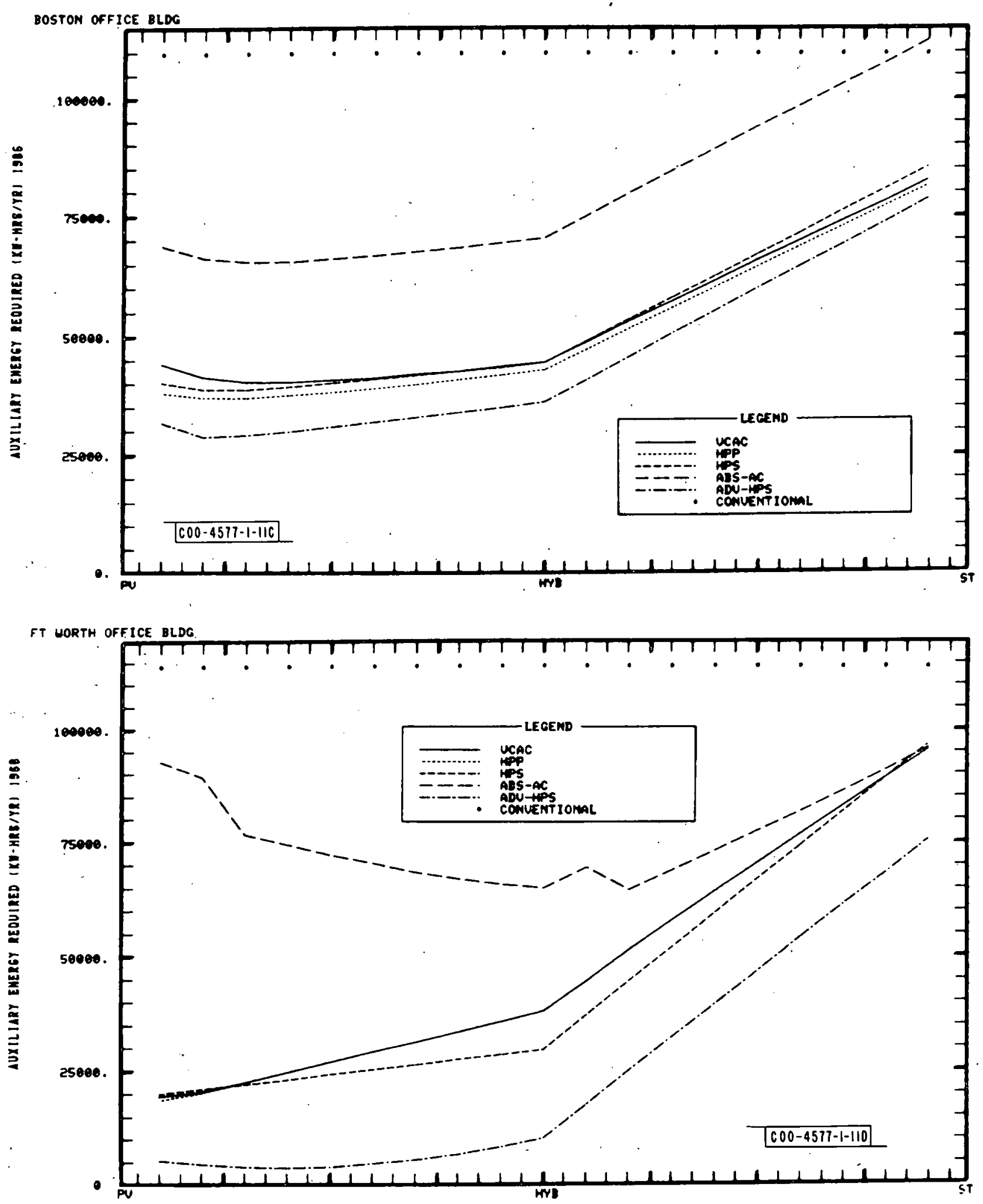

Fig. 11c,d. Auxiliary energy requirement for office building in (c) Boston and (d) Ft. Worth. 

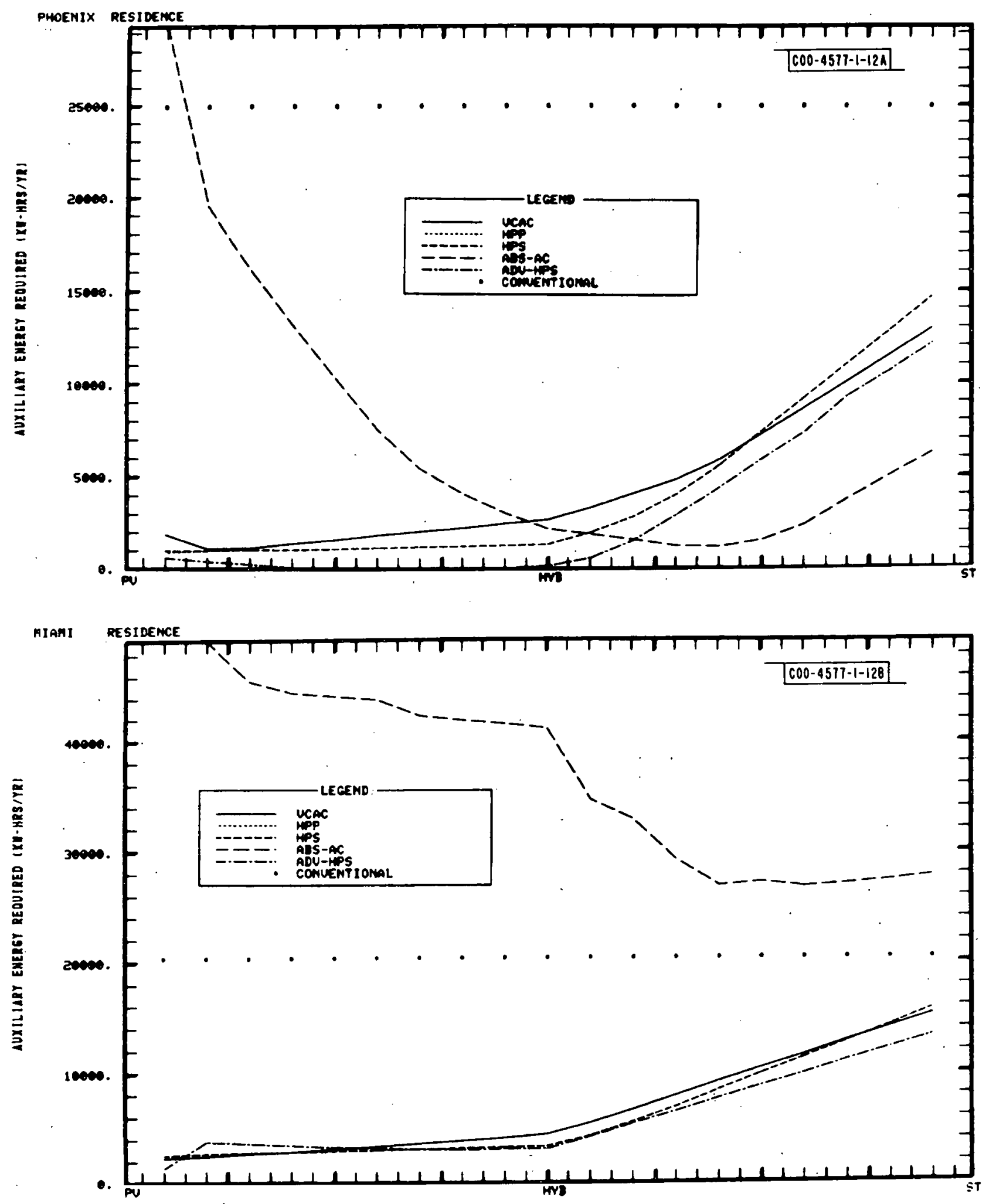

Fig. 12a,b. Auxiliary energy requirement for residences in (a) Phoenix and (b) Miami. 

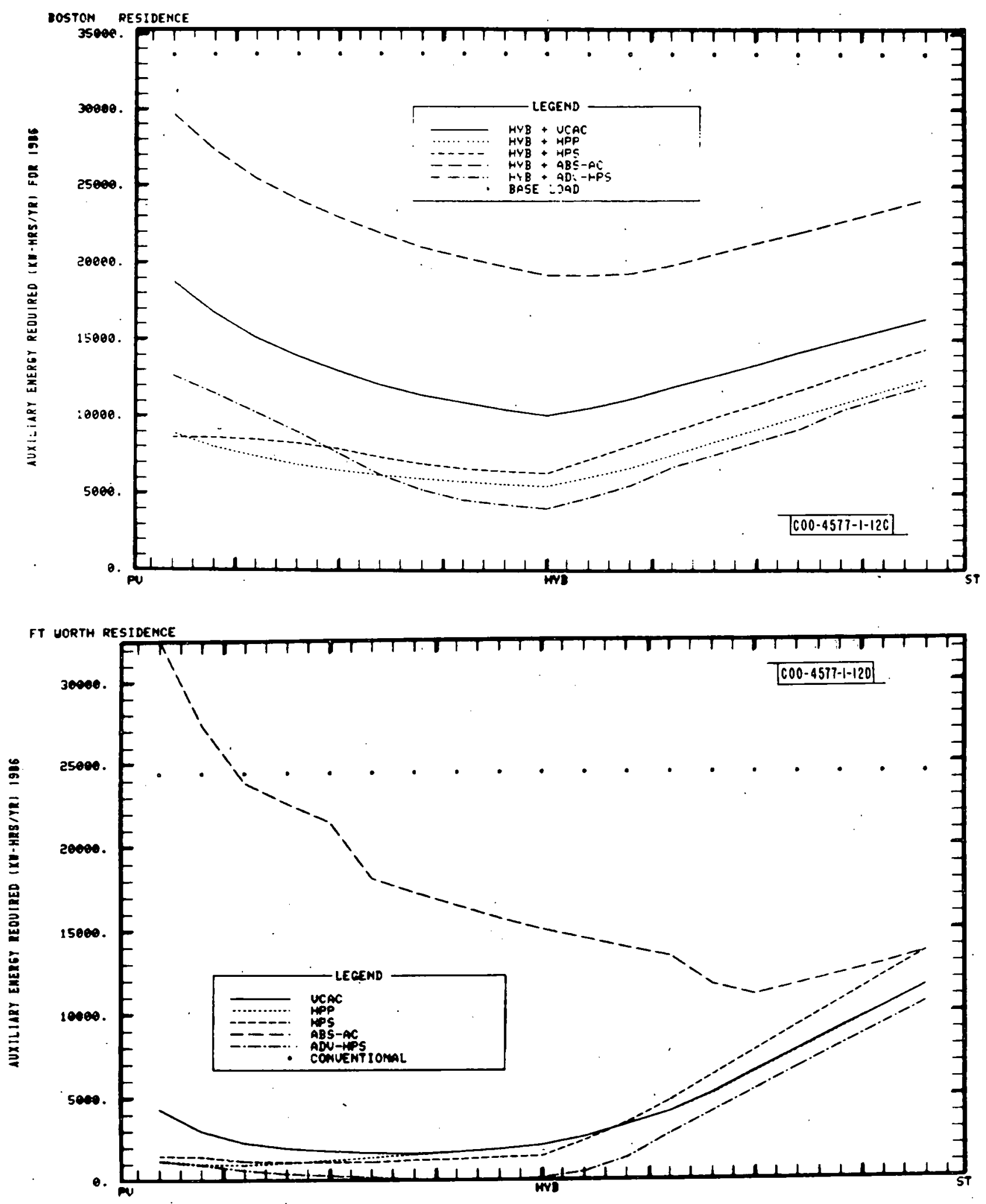

Fig. 12c,d. Auxiliary energy requirement for residences in (a) Boston and (d) Ft. Worth. 


\section{Economic Evaluation Results}

For each system, application, and location the annual system cost was generated by assuming 3- and 6-percent energy cost escalation rates (Figs. 13 and 14).

At anticipated future energy costs. all solar energy systems were more favorable economically than the conventional system. Virtually all residential system types in all four locations appear more economical than the corresponding conventional system at the 6-percent energy-growth rate.

While the advanced heat pump system appears most attractive in terms of energy savings, direct solar heating with vapor-compression air conditioning appears most economical because of its low first cost. In general, for any system, annual system cost decreases as hybrid collectors are replaced by photovoltaic modules because of the anticipated lower cost of photovoltaic modules and the greater value of electrical energy compared to thermal energy.

For the office building application, no system appeared competitive with the conventional system at the 3-percent energy-cost escalation rate because of high first costs and relatively inexpensive auxiliary energy. When hybrid collectors were replaced almost entirely by photovoltaic modules, all office building systems approached their lowest annual cost, which, at the 6-percent energy-growth rate, was slightly more economical than the conventional system. This trend was due to the collector cost assumptions and the greater cost of auxiliary electrical energy.

There is little distinction between systems for office buildings in terms of annual system cost, since the collectors make up the largest part of the initial system cost and the energy cost savings are small in comparison. The change from the 3- to 6-percent energy-escalation rate shifts the relative positions of the five systems because the differences in energy savings become more significant as the cost of auxiliary energy increased.

These economic results depend critically upon the predicted future collector and component costs as.well as the predicted energy price escalations. 

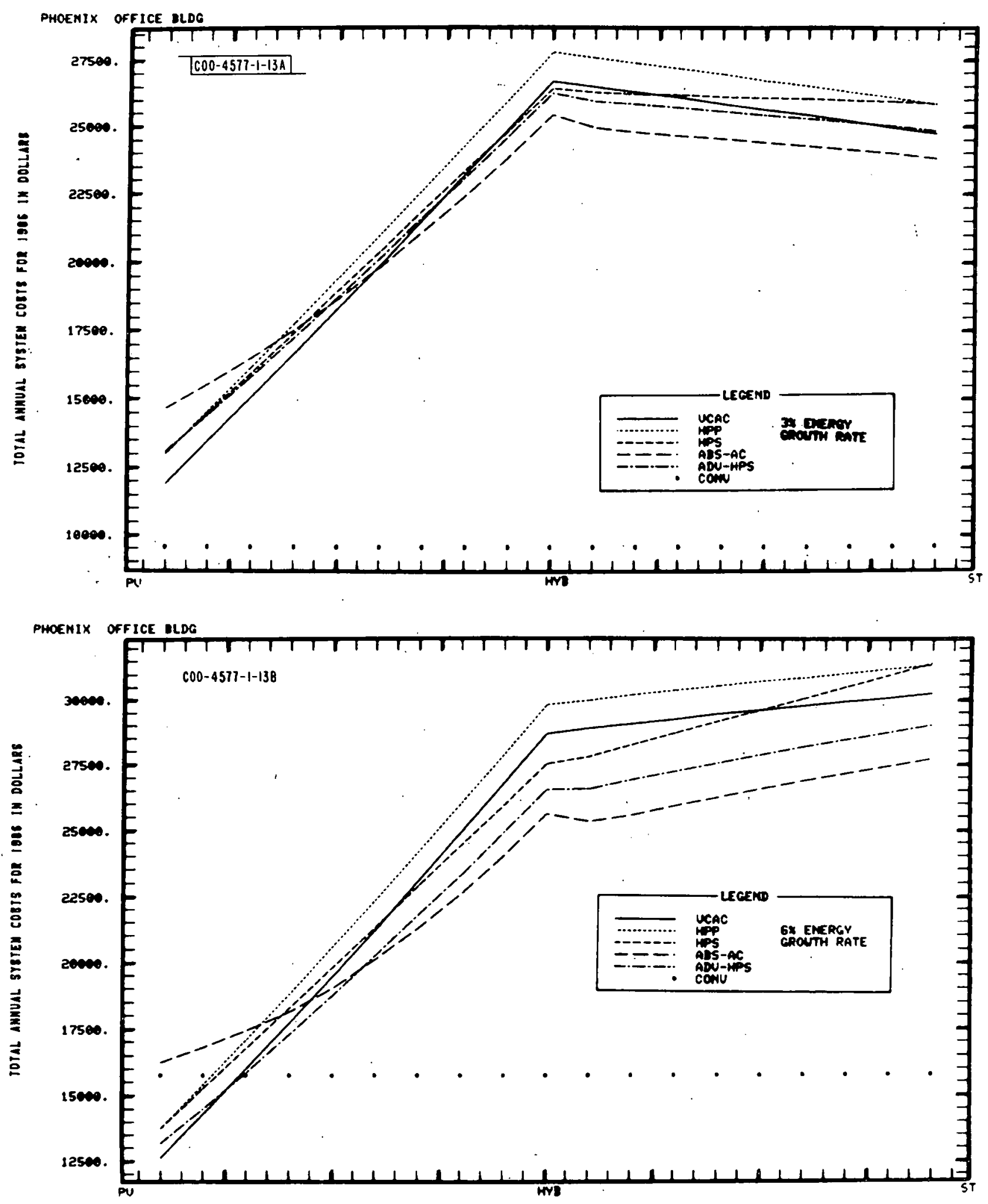

Fig. 13a,b. Annual system cost for an office building in 1986 in Phoenix at (a) 3-percent and (b) 6-percent energy-growth rates. 

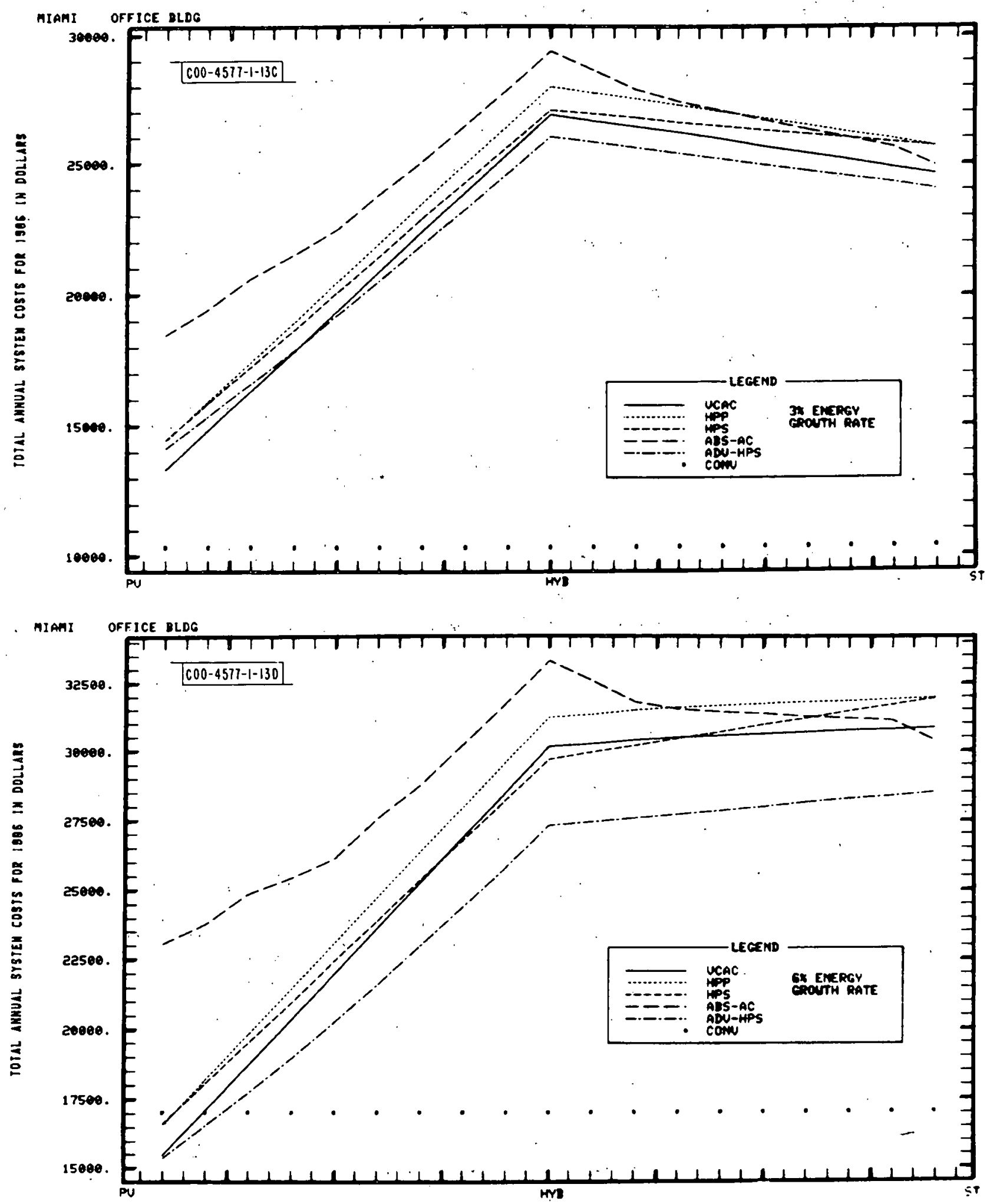

Fig. 13c,d. Annual system cost for an office building in 1986 in Miani at (c) 3-percent and (d) 6-percent energy-growth rates. 

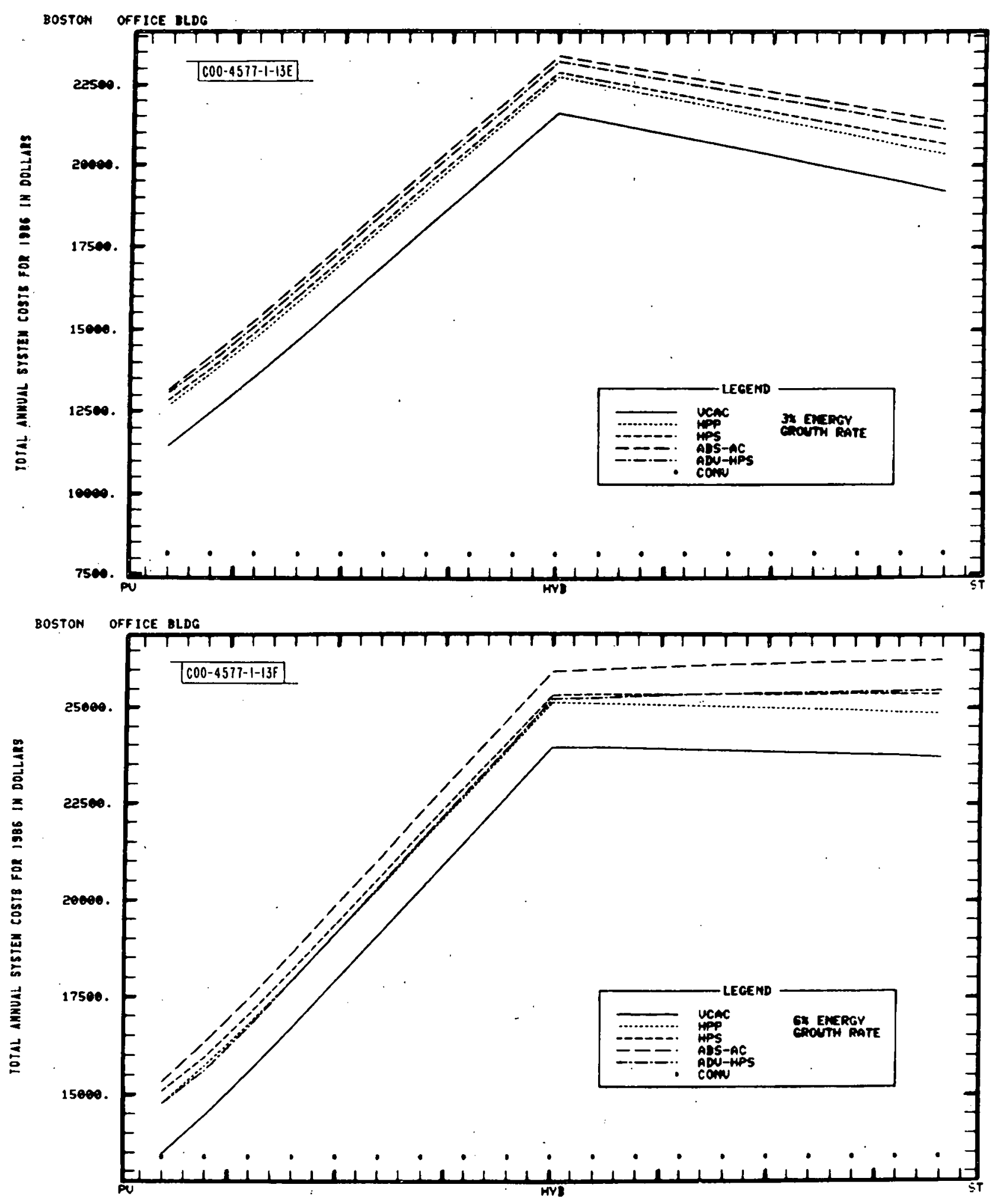

Fig. 13e,f. Annual system cost for an office building in 1986 in Boston at (e) 3-percent and (f) 6-percent energy-growth rates. 

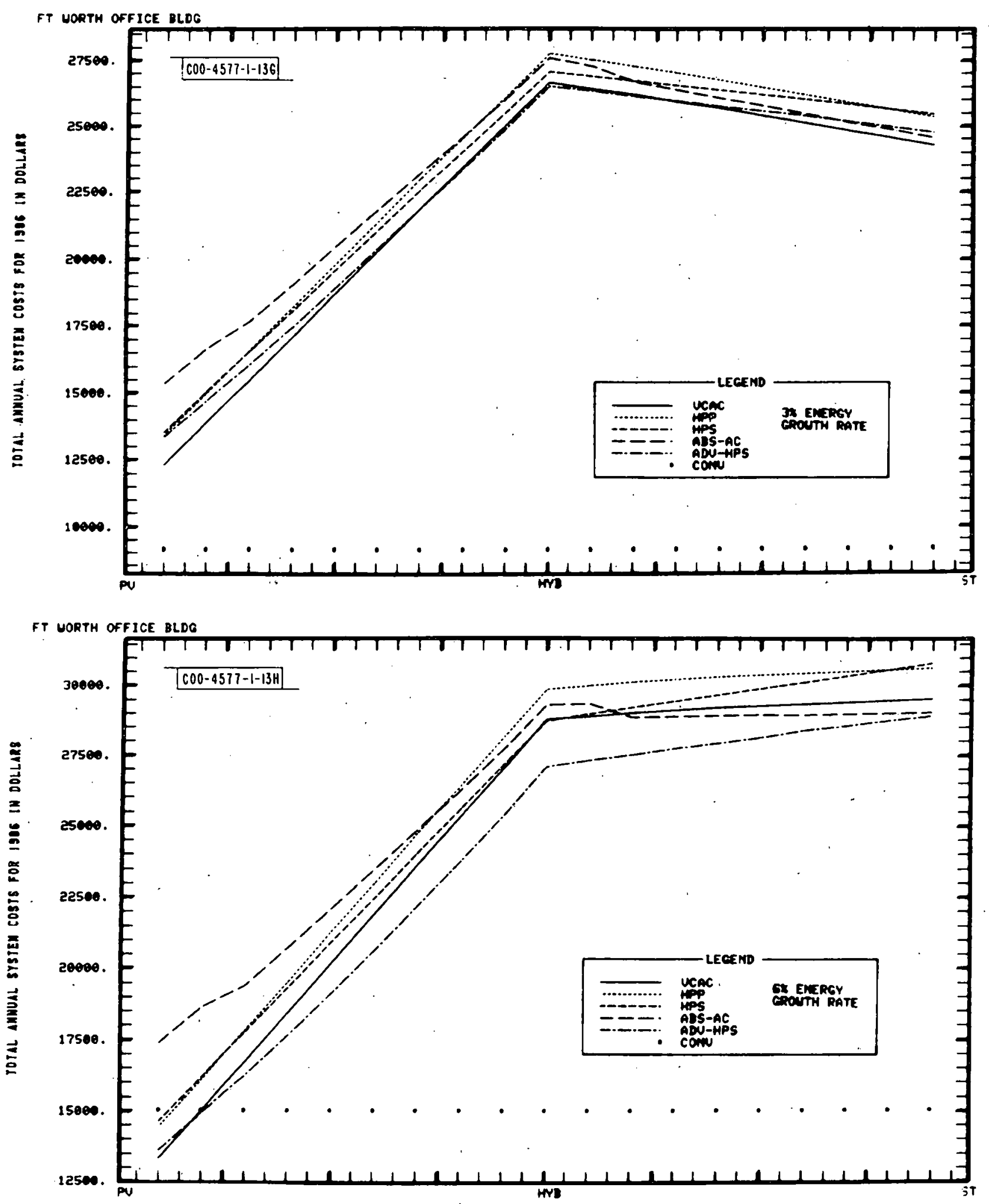

Fig. 13g, h. Annual system cost for an office building in 1986 in Ft. Worth at (g) 3-percent and $(\mathrm{h})$ 6-percent energy-growth rates. 

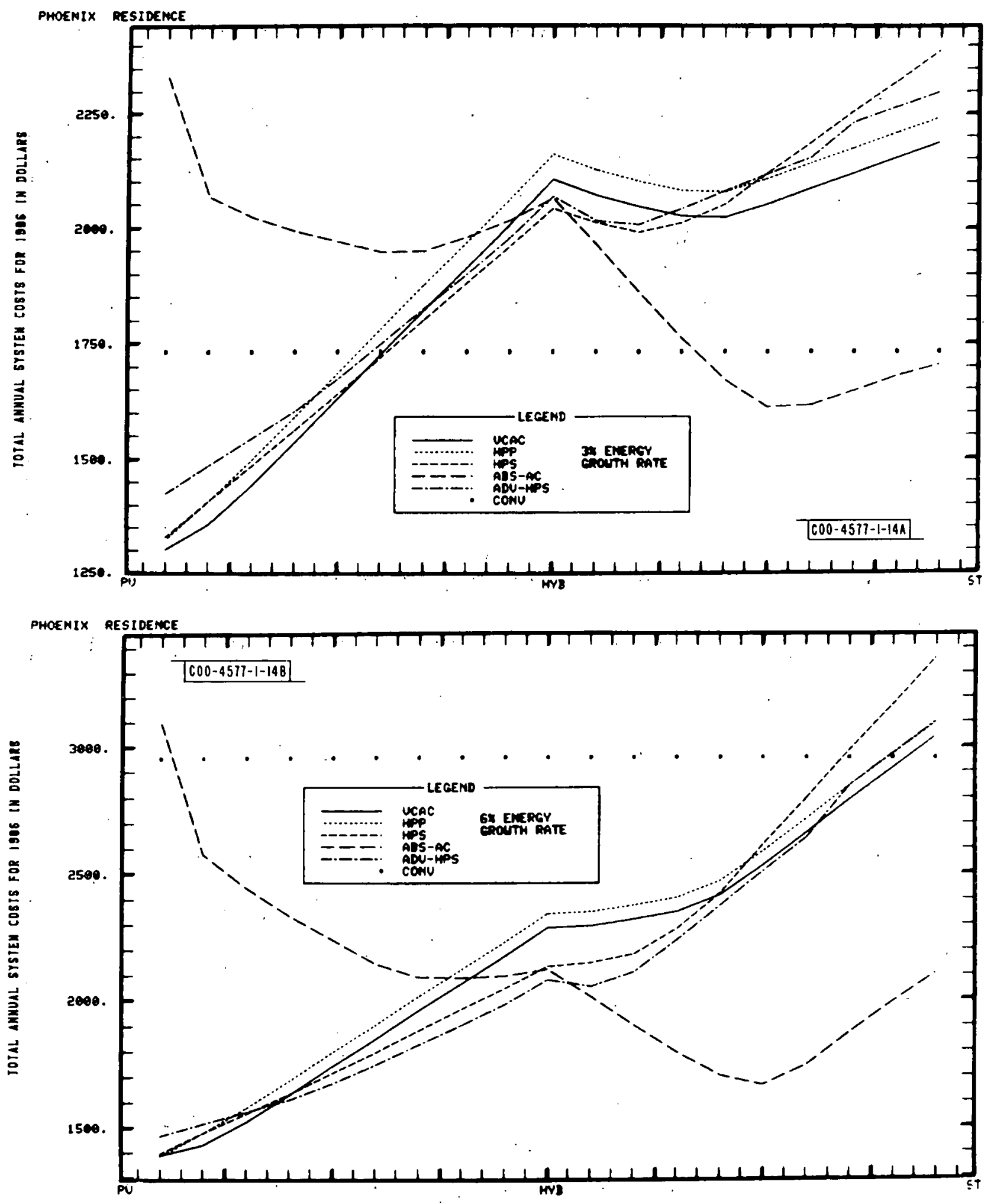

Fig. 14a,b. Annual system cost for a residence in 1986 in Phoenix at (a) 3-percent and (b) 6-percent energy-growth rates. 

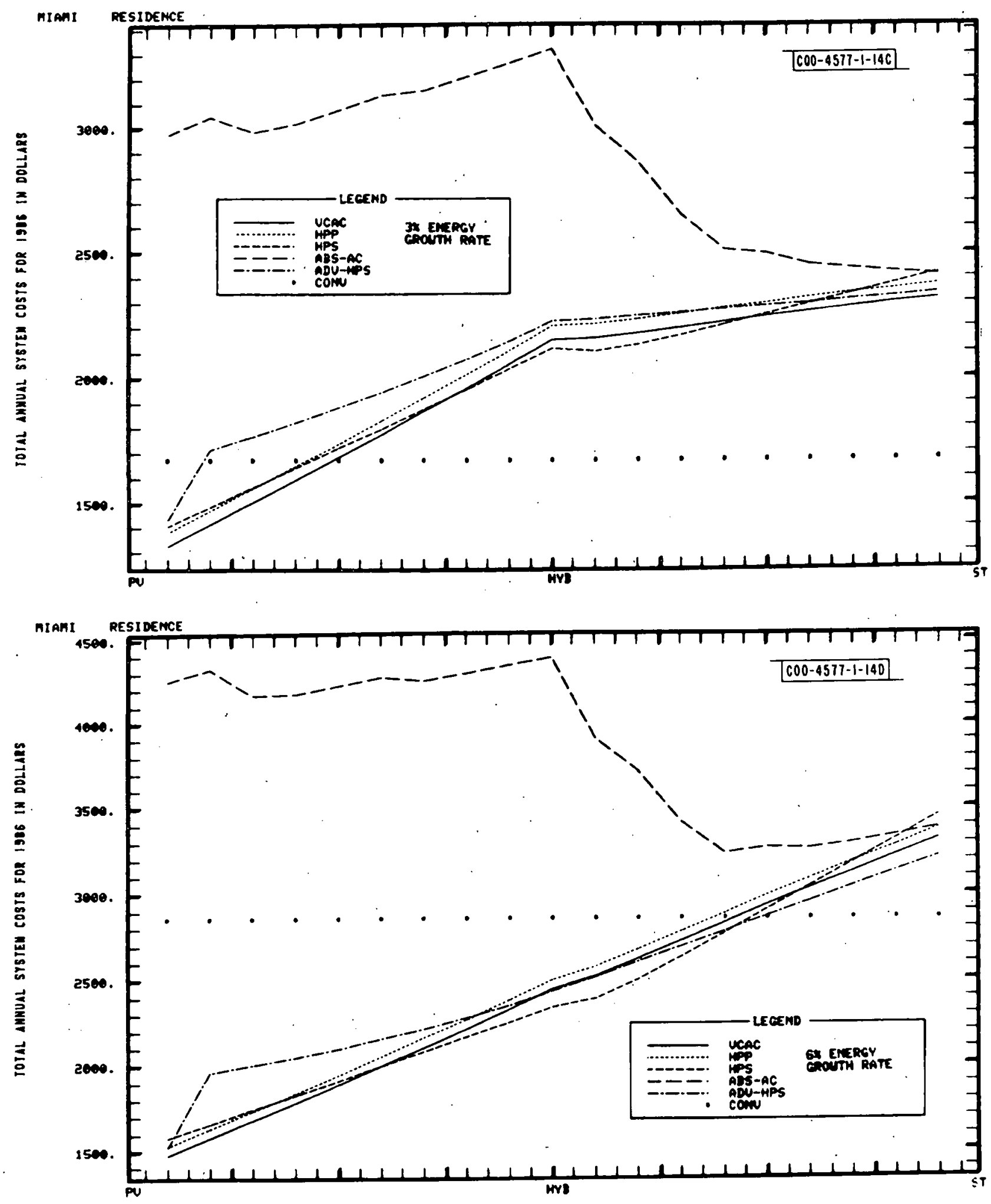

Fig. 14c, d. Annual system cost for a residence in 1986 in Miami at (c) 3-percent and (d) 6-percent energy-growth rates. 

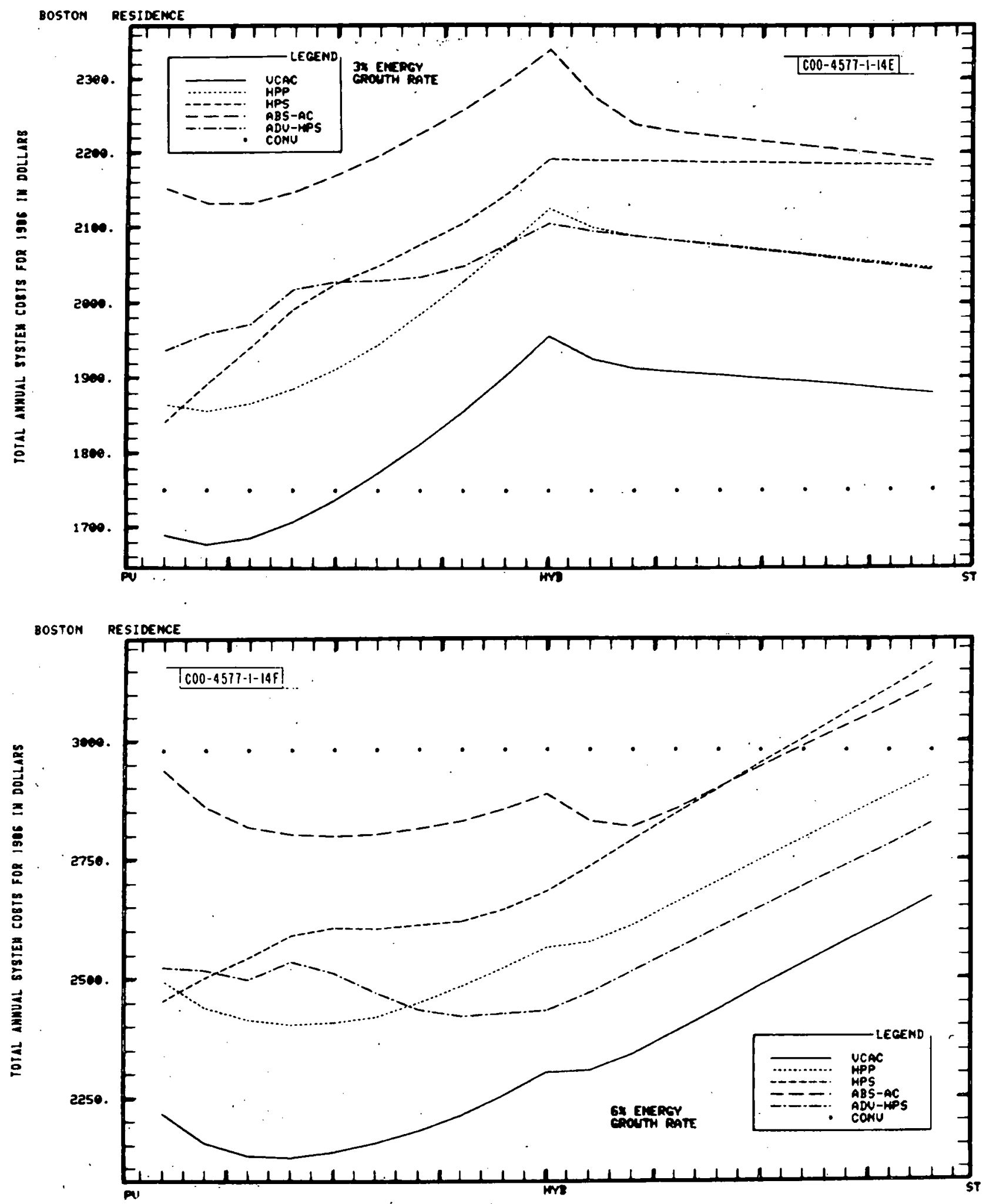

Fig. 14e,f. Annual system cost for a residence in 1986 in Boston at (e) 3-percent and (f) 6-percent energy-growth rates. 

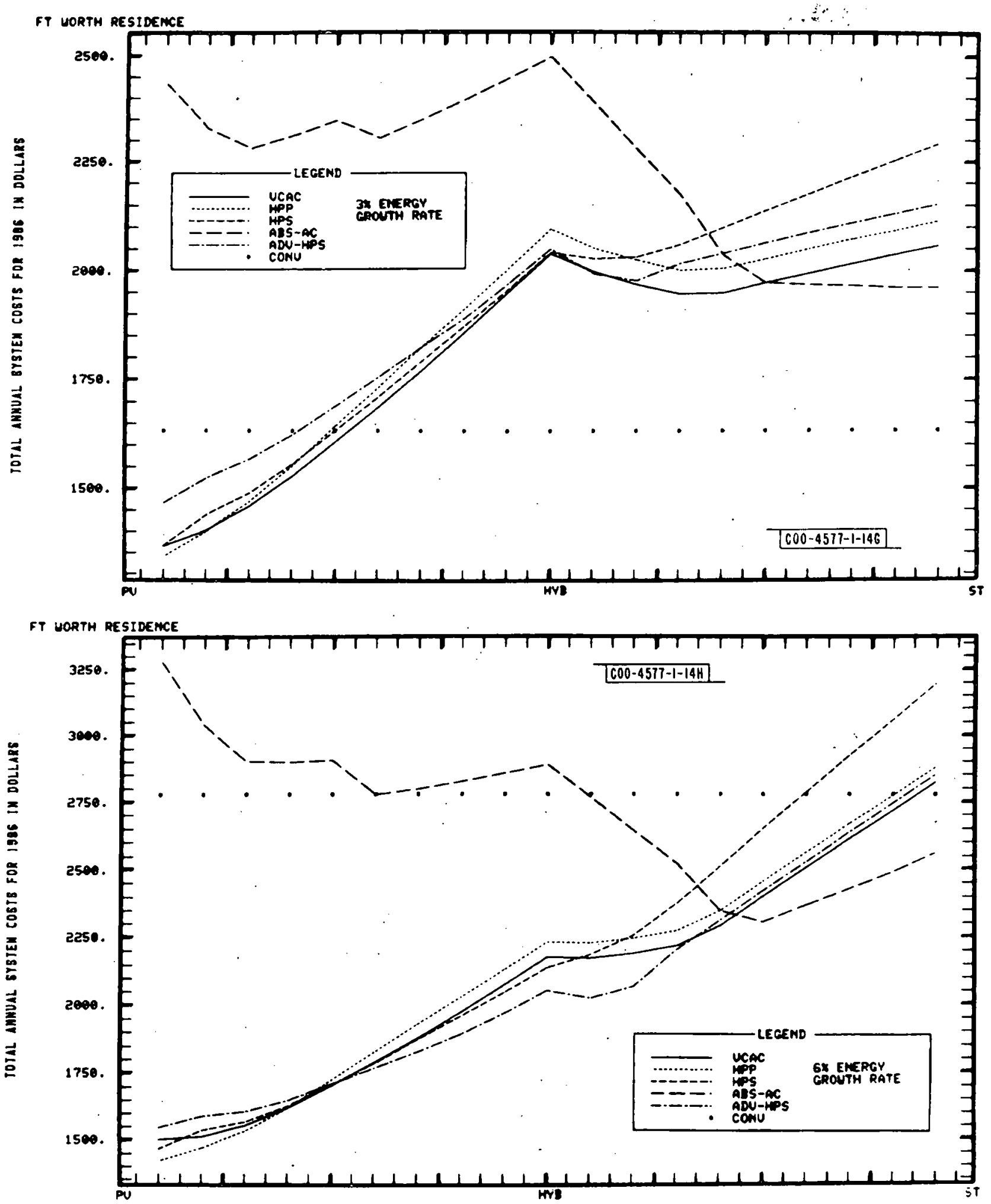

Fig. 14g,h. Annual system cost for a residence in 1986 in Ft. Worth at (g) 3-percent and (h) 6-percent energy-growth rates. 